\title{
Eğitimde Teknoloji Kullanımı İçerikli Hizmet İçi Eğitim Kurslarının Öğretmenlerin Teknolojik Pedagojik Alan Bilgisi Özgüvenine Etkileri
}

\begin{abstract}
Naci BAYRAK* , Gül BAYRAK**
Öz: Bu çalışmanın amacı; eğitimde teknoloji kullanımıyla ilgili gerçekleştirilen hizmet içi eğitimlerin etkilerini, teknolojik pedagojik alan bilgisi (TPAB) öz güven düzeyleri üzerinden incelenmesidir. Bu amaçla önce ortaokul kademesinde görev yapan 120 fen bilimleri ve lise kademesinde görev yapan 46 biyoloji, 37 fizik ve 38 kimya olmak üzere 241 fen grubu öğretmenden TPAB öz güven ölçeği ve kişisel bilgi formuyla bilgi toplanmış, daha sonrasında analiz edilen nicel verilerin derinlemesine incelenmesi amacıyla 18 öğretmenle yarı yapılandırılmış görüşme yapılmıştır. Çalışma sonucunda eğitimde teknoloji kullanımı içerikli hizmet içi eğitimlerin öğretmenlerin TPAB öz güvenlerini olumlu yönde etkilediği, ancak kursların yüz yüze veya uzaktan olmasının fark oluşturmadığı, olumlu etki eden en önemli etkenin hizmet içi eğitimlere gönüllü katılım olduğu, teknolojik bilgi alt boyutunda kurs içeriklerinin yetersiz olduğu sonuçlarına ulaşılmıştır. Eğitimde teknoloji kullanımı içerikli hizmet içi eğitimlerin hedeflenen amaçlarına ulaşması için; katılımcı öğretmenlerin aynı veya benzer branştan olması, kurs içeriğin geliştirilmesi, eğitimcilerin özellikle alanına hâkim ve iletişim gücü yüksek eğitmenlerden seçilmesi, içeriğe uygun olarak eğitimlerin kısmi olarak uzaktan ve yüz yüze gerçekleştirilmesi hususlarında öneriler sunulmuştur.
\end{abstract}

Anahtar Kelimeler: Eğitimde teknoloji kullanımı, hizmet içi eğitim, öz-güven, teknolojik pedagojik alan bilgisi, uzaktan hizmet içi eğitim.

\footnotetext{
*Dr. Erzurum İl Milli Eğitim Müdürlüğü, Email:naci.bayrak@meb.gov.tr, Orcid No: 0000-0002-7146-9354

**Doktora Öğrencisi, Atatürk Üniversitesi, Eğitim Bilimleri Enstitüsü, Email: bayrakgulbt@gmail.com, Orcid No: 00000002-5428-1659

*** Bu araştırma için Atatürk Üniversitesi Sosyal ve Beşeri Bilimleri Etik Kurulu Başkanlığında (31.12.2020 tarih ve 2020/02-15 sayıs1) etik izin alınmıştır.
}

\begin{tabular}{lll}
\hline Gönderim:27.01.2021 Kabul:18.04.2021 & Yayın:30.06.2021
\end{tabular}




\section{The Effects of In-Service Training Courses about the Use of Technology on Teachers'}

\section{Technological Pedagogical Content Knowledge Self-Confidence}

Abstract: The aim of this research is to analyze the effects of in-service training on the use of technologies in education through its impact on self-confidence levels in technological pedagogical field knowledge (TPACK). For this purpose, data were collected from 241 science group teachers, including 120 science, 46 biology, 37 physics and 38 chemistry who was working in middle and high schools in Erzurum, and semi-structured interviews were conducted with 18 teachers for the purpose of deeply examining the quantitative data analyzed afterwards. In order to collect data, "technological pedagogical field information self-confidence scale", "personal information form" and semi-structured interview form were used. As a result of the study, it was reached that in-service trainings with the use of technology in education positively affected the teachers' TPACK self-confidence, but the face-to-face or remote courses did not make a difference, the most important factor that had a positive effect was voluntary participation in in-service trainings and insufficient content in the technological knowledge dimension. In-service trainings with the use of technology in education to achieve their intended objectives; recommendations have been presented on whether the participating teachers are from the same or similar branch, the development of content, the selection of educators especially from instructors who dominate the field and have high communication power, and the partial remote and face-to-face trainings in accordance with the content.

Keywords: Technological pedagogical content knowledge, self-confidence, using technology in education, in-service education, distance in-service education.

\section{Giriş}

Fırsatları Artırma Teknolojiyi İyileştirme Hareketi (FATİH) projesi 2010 yılında Millî Eğitim Bakanlığı (MEB) tarafından uygulanmaya başlanmış ve araştırmanın gerçekleştirildiği tarihte halen devam eden bir projedir. FATİH projesinin beş alt boyutu; donanım ve yazılım altyapısının sağlanması, eğitsel e-içeriğin sağlanması ve yönetilmesi, öğretim programlarında etkin BT kullanımı, öğretmenlerin hizmet içi eğitimi, bilinçli, güvenli, yönetilebilir ve ölçülebilir BT kullanımıdır (MEB, 2020). Milli Eğitim Bakanlığı bütün öğretmenlerin öğretim sürecinde teknolojiyi etkin kullanması amacıyla yüz yüze olarak eğitimde teknoloji kullanımı hizmet içi eğitim kursuna veya çevrim içi olarak etkileşimli sınıf yönetim kursuna katılması istenmiştir (MEB, 2016). FATİH projesi hizmet içi eğitimlerine çok büyük oranda öğretmenlerin katılımı sağlanmıştır. Çalışmanın yapıldı Erzurum ilinde 10900 öğretmenin 
bulunmakta ve 2010- 2020 yılları arasında bu öğretmenlerin \%72’si FATİH projesi kapsamında gerçekleştirilen eğitimde teknoloji kullanımı içerikli hizmet içi eğitimlere katılmıştır. Hizmet içi eğitimlere katılan 4580 öğretmen eğitimde teknoloji kullanımı kursuna, 3310 öğretmen etkileşimli sınıf yöntemi kursuna katılmıştır (Erzurum İl Milli Eğitim Müdürlüğü, 2019). Bu sayıların tüm Türkiye'de benzer olduğu düşünüldüğünde FATİH projesi sayesinde öğretmenlerin çok büyük bir bölümünün eğitimde teknoloji kullanımı içerikli hizmet içi eğitimlere katılması sağlanmıştır. 2019 son dönemlerinde dünyada meydana gelen COVID-19 salgını sebebi ile okulların uzaktan eğitime geçmesi ve bundan sonraki süreçte uzaktan, yüz yüze eğitimin beraber yürütülebileceği düşünülerek ve öğretmenlerin eğitimde teknoloji araçlarını aktif kullanmalarının önemi daha da artmıştır. Ancak Bayrak ve Hırça (2016), Demirer ve Dikmen (2018), Kayaduman, Sırakaya ve Seferoğlu (2011), Sarıtepeci, Durak ve Seferoğlu (2016), Tatli ve Akbulut (2017), Yılmaz ve Üredi (2020) çalışmalarında Türkiye de öğretmenlerin eğitimde etkin teknoloji kullanımı konusunda yetersiz olduğunu ortaya koymuştur. Ayata, Uçkan, Çavuş ve Seyyarer (2021) öğretmenlerin eski alışkanlıkları nedeni ile eğitimde teknoloji kullanımında tereddüt ettiklerini ifade etmiştir. Eğitimde teknoloji kullanımı içerikli yukarıda ifade edilen büyük çaplı hizmet içi faaliyetlerine rağmen öğretmenlerin eğitim teknolojileri konusundaki durumların yetersizliği her yönü ile araştırılması gereken bir konudur.

\section{FATİH Projesi}

FATİH projesi kapsamında 25 saatlik yüz yüze eğitimde teknoloji kullanım kursu veya bunun alternatifi olarak kabul edilen ve uzaktan eğitim olarak yürütülen 30 saatlik etkileşimli sınıf yönetim kursunun bütün öğretmenler tarafından alınması zorunlu tutulmuştur. FATİH projesi eğitimde teknoloji kullanım kursu ve etkileşimli sınıf yöntemi kursu içerikleri Tablo 1'de sunulmuştur. Etkileşimli sınıf yönetimi kursunda etkileşimli sınıf yönetimi yazılımı konusu hariç diğer bütün içerikler eğitimde teknoloji kullanım kursu ile aynıdır.

Tablo 1. FATİH projesi eğitimde teknoloji kullanımı içerikli kurslarının konu zaman dağılımı

\section{Konular}

Eğitimde

Fatih Projesi ve Proje Donanımları

Eğitimde Teknoloji Kullanımı ve Temel

Kavramlar

Öğretim Sürecinde materyal Kullanımı

E-Materyal, Arama, Seçme ve Düzenleme
Konu için ayrılmış süre (saat)

\section{Etkileşimli Sınıf}

$\begin{array}{ll}4 & 4 \\ 3 & 3 \\ 2 & 3 \\ 5 & 6\end{array}$


Etkileşimli Sınıf Yönetimi Yazılımı

Teknoloji Destekli Ders İşlenişi

Materyalin Etkililiğinin ve Verimliliğinin

Öğretmen Tarafından Değerlendirilmesi

Bu çalışmada FATİH projesi kapsamında gerçekleştirilen eğitimde teknoloji kullanımı içerikli hizmet içi eğitim kurslarının etkilerini incelemek amacıyla TPAB konusunda öz güven boyutu seçilmiştir. Eğitimde teknoloji kullanımında öz güven önemli bir göstergedir (Kayaduman vd., 2011; Tatli ve Akbulut, 2017). Kısa tanımı ile öz güven; öğretim görevini gerçekleştirmek amacıyla gerekli olan etkinlikleri organize etme, yürütme becerisine olan inançtır (Tschannen-Moran, Hoy ve Hoy 1998). Öğretmenlerin nitelikli olması öğretim sürecini olukça olumlu etkileyecek bir ölçüttür. Teknoloji destekli işlenen derslerin öğrenciler tarafından daha iyi kavranıp hatırlanacağı düşünülmektedir (Bağdiken ve Akgündüz, 2018; Mishra ve Koehler, 2006). Bundan dolayı öğretmenlerinin teknolojiyi etkin ve verimli bir şekilde kullanmaları, teknoloji okuryazarı olmaları gerekmektedir (Bağdiken ve Akgündüz, 2018; Niess, 2008).

Öz güveni yüksek olan öğretmenler teknolojik sistemleri öğretim yöntemlerine daha kolay entegre edebileceklerdir (Çalışkan ve Çoklar, 2019). Günümüz okullarında eğitim alan öğrenciler Z-kuşağı olarak isimlendirilmektedir. Z kuşağının temel özelliklerinden biri; teknolojiyi kullanmaları ve öğrenim süreçlerinde motivasyon aracı olarak teknolojiye ihtiyaç duymalarıdır (Somyürek, 2014). Z-kuşağı öğrencilerinin öğrenme süreçlerine destek sağlayacak öğretmenlerin, teknolojiyi, pedagoji ve alan bilgisi ile harmanlayıp öğretim sürecinde kullanmaları beklenmektedir. TPAB; pedagoji ve alan bilgisinin ötesinde bir bilgidir. Shulman (1986) tarafından geliştirilen pedagojik alan bilgisine (PA), teknoloji boyutunun eklenmesiyle ortaya çıkmıştır (Mishra ve Koehler, 2006).

TPAB konusunda Türkiye'de yapılan çalışmaların büyük çoğunluğu TPAB yeterliliği, gelişimi, ölçek geliştirme, TPAB programını değerlendirme konularında yoğunlaşmaktadır (Baran ve Canbazoğlu Bilici, 2015; Kaleli Yılmaz, 2015). Yine yapılan çalışmaların çok büyük kısmı öğretmen adayları ile yürütülmüş olup, öğretmenlerle yapılan çalışma sayısı oldukça azdır (Kaleli Yılmaz, 2015). Öğretmenlerin TPAB konusundaki bilgilerinin temelleri üniversite eğitimi sırasında atılmasına rağmen, görev başındaki öğretmenlere de bu konuda eğitimler vermek çok önemlidir (Padmavathi, 2017). 
Türkiye'de TPAB çalışmaları içinde öğretmenlerin öz güvenlerine yönelik Bağdiken ve Akgündüz, (2018), Akyüz, Pektaş, Kurnaz ve Memiş (2014), Bal ve Karademir (2013), Meriç (2014), Özkara, Konokman ve Yelken (2018), Tatlı, İpek Akbulut ve Altınışık (2016), Tokmak, İncikabı ve Özgelen (2013), Uçar, Demir ve Hiğde (2014) çalışmaları yer almaktadır. Bu çalışmalarda ortak olarak cinsiyetin, mesleki deneyimin, bilgisayar sahibi olma veya teknolojiye erişme bağımsız değişkenlerinin TPAB öz güvenine etkisi incelenmiştir.

Öğretmenlerin teknoloji kullanımı konusunda aldıkları eğitimler, teknolojik pedagojik alan bilgisi öz güvelerinde kuşkusuz önemli bir etkiye sahiptir (Bağdiken ve Akgündüz, 2018). Bağdiken ve Akgündüz (2018), Bal ve Karademir (2013), Özkara vd. (2018) çalışmasında eğitim teknolojileriyle ilgili eğitim alan öğretmenlerin almayanlara göre TPAB öz güvenlerinin araştırılan her boyutta daha yüksek olduğunu tespit etmişlerdir. Kocaoğlu ve Akgün (2015) FATİH projesi eğitimde teknoloji kullanım kurslarına katılan öğretmenlerin FATİH projesi donanımlarını kullanma yönünden öz güvenlerinin yüksek olduğunu tespit etmiştir. Bahsi geçen dört çalışmada da (Bağdiken ve Akgündüz, 2018; Bal ve Karademir, 2013; Özkara vd., 2018; Kocaoğlu ve Akgün, 2015) hizmet içi eğitimlerin artırılması, daha çok öğretmenin bu kurslara katılmalarının sağlanmasını önermişlerdir. Bu çalışmalardan faklı olarak eğitimde teknoloji kullanımı içerikli hizmet içi eğitimlerinin öğretmenlerin ihtiyacını karşılayamadığı (Sarıtepeci vd., 2016), teknolojik pedagojik yetenekleri kazandırmada yetersiz kaldığ (Vural ve Ceylan, 2014), kısa süreli eğitim konferans, öğretmen atölyelerinin öğretmenlerin yeni yeterlilikler kazanması hususunda kalıcı etkiye sahip olmadığı (Carlson ve Gadio, 2002; Enochsson ve Rizza, 2009), özellikle teknolojik pedagojik alan bilgisi öz güvenlerinin hizmet içi eğitimlere rağmen düşük kaldığı (Lehiste, 2015) yönünde çalışmalarda alan yazında yer almaktadır. Bu bakımdan eğitimde teknoloji kullanımı içerikli hizmet içi eğitimlerin öğretmenlere etkileri konusuna alan yazında tam bir fikir birliği olmadığı görülmektedir. Yine çalışmalarda hizmet içi eğitimlerin uzaktan veya yüz yüze olması, öğretmenlerin kurslara gönüllü veya gönülsüz katılımlarının TPAB öz güvenlerine etkisinin olup olmadığı konusunda bir çalışmaya rastlanmamıştır. Alan yazımdaki bu eksiliklerden hareketle; FATİH projesi kapsamında gerçekleştirilen, eğitimde teknoloji kullanımı içerikli hizmet içi eğitim kurslarının çeşitli özelliklerinin öğretmenlerin TPAB öz güvenlerine etkilerinin incelenmesi alan yazıma katk1 sağlayacağ1 düşünülmektedir.

Bu bağlamda araştırmada aşağıdaki sorulara cevap aranmıştır:

- Çalışmaya katılan öğretmenlerin TPAB öz güven düzeyleri nedir? 
- Çalışmaya katılan öğretmenlerin TPAB öz güvenlerinde; lisans eğitimi sırasında bilişim teknolojileri (BT) dersini almaları, hizmet içi olarak eğitim teknolojileri kullanımı konusunda kurslara katılmış olmaları, katıldıkları kursların uzaktan veya yüz yüze olması, kurslara gönüllü veya gönülsüz katılma değişkenlerine göre farklılık var mıdır?

\section{Yöntem}

Araştırmada nicel verilerin derinlemesine açıklanması amacıyla karma araştırmada desenlerinden açıklayıcı ardışık desen kullanılmıştır (Creswell, 2017). Açıklayıcı ardışık desende önce nicel veriler toplanıp analiz edilir, daha sonra nicel sonuçları açıklamak için nitel çalışma yürütülür (Creswell, 2017). Bu çalışmada da öncelikle öğretmenlerden ölçek yardımı ile bilgiler toplanıp, analiz edilmiş ve analiz sonuçlarının açıklanması için hizmet içi eğitimlerde kursiyer veya eğitimci olarak görev yapan öğretmenlerden yarı yapılandırılmış görüşmeler yolu ile veri toplanmıştır.

\section{Örneklem}

Araştırmanın örneklemi Erzurum ilinde 2019-2020 öğretim yılında görev yapan fen bilimleri, biyoloji, fizik ve kimya branşlarından toplam 241 öğretmenden oluşmaktadır. Ölçeğin uygulanması konusunda il milli eğitim müdürlügünden gerekli izinler ve etik kurul izini alındıktan sonra Google form aracılığı ile online hale getirilerek Erzurum ilinde görev yapan bütün fizik, kimya, biyoloji ve fen bilimleri öğretmenlerine iletilmiştir. Ölçeğin başlangıç kısmına araştırmanın amacı, ölçekte kimlik belirtecek bilgi istenmediği, katılımın tamamen gönüllü olduğu açıklamalarına yer verilmiştir. Ölçeği 300 öğretmen doldurmuş ancak 69 öğretmenin branşlarının istenilen branşlarda olmaması, cevapları eksik veya hatalı olmasından dolayı değerlendirmeye katılmamıştır. Google formda öğretmenlerin sorulara özgürce cevap vermeleri için sorular zorunlu tutulmamıştır. Verileri değerlendirilen öğretmenlerin demografik bilgileri tablo 2 de sunulmuştur.

Tablo 2. Çalışmaya Katılan Öğretmenlerin Demografik Bilgileri

\begin{tabular}{ccccccccccccc}
\hline & & Biyoloji & \multicolumn{2}{c}{$\begin{array}{c}\text { Fen } \\
\text { Demografik Özellik }\end{array}$} & & \multicolumn{2}{c}{ Bilimleri } & \multicolumn{2}{c}{ Fizik } & \multicolumn{2}{c}{ Kimya } & \multicolumn{2}{c}{ Toplam } \\
\cline { 3 - 13 } & $f$ & $\%$ & $f$ & $\%$ & $f$ & $\%$ & $f$ & $\%$ & $f$ & $\%$ \\
\hline \multirow{2}{*}{ Cinsiyet } & Kadın & 31 & 67,4 & 77 & 64,2 & 14 & 37,8 & 19 & 50 & 141 & 58,5 \\
& Erkek & 15 & 32,6 & 43 & 35,8 & 23 & 62,2 & 19 & 50 & 100 & 41,5
\end{tabular}




\begin{tabular}{llcccccccccc} 
& Toplam & 46 & 100,0 & 120 & 100,0 & 37 & 100,0 & 38 & 100,0 & 241 & 100,0 \\
\hline & $1-10$ yıl & 35 & 76,1 & 91 & 75,8 & 19 & 51,4 & 24 & 63,2 & 169 & 70,1 \\
$\begin{array}{l}\text { Mesleki } \\
\text { Deneyim }\end{array}$ & $11-21$ yıl & 11 & 23,9 & 29 & 24,2 & 18 & 48,6 & 14 & 36,8 & 72 & 29,9 \\
& Toplam & 46 & 100,0 & 120 & 100,0 & 37 & 100,0 & 38 & 100,0 & 241 & 100,0 \\
\hline & Eğitim & 21 & 45,7 & 112 & 93,3 & 13 & 35,1 & 12 & 34,2 & 159 & 66,0 \\
$\begin{array}{l}\text { Mezun } \\
\text { olduğu } \\
\text { fakülte }\end{array}$ & Fen & 25 & 54,3 & 8 & 6,7 & 24 & 64,9 & 25 & 65,8 & 82 & 34,0 \\
\hline & Toplam & 46 & 100,0 & 120 & 100,0 & 37 & 100,0 & 38 & 100,0 & 241 & 100,0 \\
\hline $\begin{array}{l}\text { Görev } \\
\text { yeri }\end{array}$ & İlçe & 22 & 47,8 & 62 & 51,7 & 13 & 35,1 & 15 & 39,5 & 112 & 46,5 \\
& Toplam & 46 & 100,0 & 120 & 100,0 & 37 & 100,0 & 38 & 100,0 & 241 & 100,0 \\
\hline
\end{tabular}

Çalışma 120 fen bilimleri, 46 biyoloji, 37 fizik, 38 kimya olmak üzere toplam 241 öğretmen ile yürütülmüştür. Öğretmelerin \%58,5'i kadın, \%41,5'i erkektir. Mesleki deneyim bakımından \%70’i 1-10 yıl, \%29,9’u 11-20 yıl mesleki deneyime sahiptir. Mezun olunan fakülte bakımından \%66,0's1 eğitim fakültesi, 34,0’ü fen fakültesi mezunudur. Görev yeri bakımından \%53,3'ü Erzurum şehir merkezinde, \%46,7'si, ilçelerde görev yapmaktadır.

Nicel bulguların derinlemesine incelenmesi maksadıyla amaca uygun örneklem yöntemi ile 18 öğretmenden görüşme yolu ile veri toplanmıştır. Görüşme yapılan 6 öğretmen eğitimde teknoloji kullanım kurslarında eğitici olarak görev almış, 12 öğretmen eğitimde teknoloji kullanımı içerikli hizmet içi eğitim kurslarına katılmıştır. Görüşme yapılacak eğitici öğretmen seçilirken eğitim verdiği kurs sayısının fazla olmasına dikkat edilmiştir. Yine kurslara katılan öğretmenlerden 6 öğretmen yalnızca uzaktan eğitim yoluyla, 6 öğretmen farklı zamanlarda hem uzaktan hem de yüz yüze eğitimde teknoloji kullanımı içerikli hizmet içi eğitime katılmış öğretmenlerden seçilmiştir.

\section{Çalışmada Kullanılan Veri Toplama Araçları}

Veri toplama aracı olarak "Teknolojik pedagojik alan bilgisi öz güven ölçeği”, "kişisel bilgi formu" ve nicel verilerin açıklanmasın da kullanılmak üzere gerçekleştirilen yarı yapılandırılmış görüşme soruları kullanılmıştır.

Teknolojik pedagojik alan bilgisi öz güven ölçeği: Graham, Burgoyne, Cantrell, Smith, Clair ve Harris (2009) tarafından 6'lı likert tipte geliştirilen ölçek Timur ve Taşar (2011) tarafından Türkçe'ye uyarlanırken 5'li likert tipte düzenlenmiştir. Ölçek dört boyutta, 31 
maddeden oluşmaktadır: 1-8. maddeler: Teknolojik pedagojik alan bilgisi (TPAB), 9.-15. maddeler: Teknolojik pedagojik bilgi (TPB), 16.-20. maddeler: Teknolojik alan bilgisi (TAB) ve 21.-31. maddeler: Teknolojik bilgi (TB) ölçmektedir. Ölçeğin NFI=0,87 ve RMSEA=0,069 çıkmıştır (Timur ve Taşar, 2011). Ölçek genelinin güvenirlik katsayısı (Cronbach Alfa): 0.92, alt boyutların ise sırasıyla 0,89,0,87, 0,89 ve 0,86 olarak belirtilmiştir (Timur ve Taşar, 2011). $\mathrm{Bu}$ araştırmada ise ölçeğin genel güvenirlik katsayısı (Cronbach Alfa): 0,887, alt boyutlarda ise $\mathrm{TPAB}=0,835, \mathrm{TPB}=0,831, \mathrm{TAB}=0,880, \mathrm{~TB}=0,875$ olarak bulunmuştur. $\mathrm{Bu}$ hali ile ölçeğin araştırma için güvenilir olduğu söylenebilir.

Kişisel bilgi formu: Araştırmacılar tarafından geliştirilen form ile öğretmenlerin cinsiyet, mesleki deneyim, mezun olduğu okul, eğitimde teknoloji kullanımı içerikli hizmet içi eğitim kurslarına katılma durumu, kullandıkları Web 2.0 araçları hakkında bilgiler toplanmaya çalışılmıştır.

Yarı yapılandırılmış görüşme soruları: Nicel bulguları derinlemesine açıklayabilmek için yarı yapılandırılmış görüşme formu hazırlanmıştır. Bu amaçla öncelikle nicel veriler analiz edilmiş, elde edilen bulgularda araştırmacılar tarafından açıklanmasına ihtiyaç duyulan durumlara yönelik sorular hazırlanmıştır. Hazırlanan sorular bir Türk dili edebiyatı öğretmeni ve bilgisayar öğretim teknolojileri alanında doktora yapmış bir öğretmenin görüşüne sonulmuş, alınan dönütlerden sonra düzenleme yapılmıştır, sonrasında sorular eğitimde teknoloji kullanımı içerikli hizmet içi eğitimlerde eğitim görevlisi olarak görev almış bir ve hizmet içi eğitim kursiyer olarak katılmış üç öğretmenle pilot olarak görüşmede kullanılmış, forma gerekli düzenlemeler yapılarak son hali verilmiştir. Çalışmada kullanılan yarı yapılandırılmış görüşme formunda yer alan sorular ve amaçları tablo 3 de sunulmuştur.

Tablo 3. Görüşme formu soruları ve soru amaçları

\section{Soru amacı Soru}

Eğitimde teknoloji kullanımı Eğitimde teknoloji kullanımı konusunda hizmet içi içerikli kurslara katılan eğitimlere katılmış öğretmenlerin TPAB; TAB; öğretmenlerin teknolojik bilgi TPB alt boyutlarında öz güvenlerinde anlamlı boyutunda öz güvenleri neden düzeyde gelişme olurken TB alt boyutunda değişim düşük olduğunu ortaya çıkarmak olmamıştır.

- Bu durumun nedeni sizce nedir?

- Neden teknolojik bilgi konusunda öz güven yeterince gelişememiştir?

Teknolojik bilgi alt boyutunda öz güvenlerinin en düşük olduğu; video düzenleme, web 2.0 araçları
TB öz güven konusunda sorulan sorulardan video düzenleme, web sayfasını oluşturma, web 2.0 
kullanma, web sitesi hazırlama araçlarını kullanma konusunda özgüven konusunda katıldıkları kurslardaki eksiklikleri ortaya çıkarma ortalamaları en alt seviyededir.

- Video düzenleme, Web 2.0 araçlarını kullanma web sitesi oluşturma konusunda hizmet içi eğitimlere katılan öğretmenlerin ortalamaları sizce neden düşüktür?

Eğitimde teknoloji kullanımı içerikli hizmet içi eğitimler konusunda öğretmenlerin ve eğiticilerin yaşadıkları sorun ve önerileri ortaya çıkarma
Katıldığınız, diğer öğretmenlerin katıldığ 1 veya eğitim verdiğiniz kursları düşünerek;

- Uzaktan ve yüz yüze hizmet içi eğitimlerin üstün ve zayıf yönleri nelerdir?

- Eğitimde teknoloji kullanımı içerikli bir kursa katılmanız istenirse uzaktan eğitimi mi, yüz yüze eğitimi mi tercih edersiniz? Neden?

- Katıldığınız hizmet içi eğitim kurslarında en sık yaşadığınız problemler nelerdir?

- Eğitimde teknoloji kullanımı içerikli hizmet içi eğitimleri sizin planlamanız gerekseydi neleri değiştirirdiniz?
Birbiri ile hemen hemen aynı içerikli olmasına rağmen öğretmenlerin neden hem uzaktan hem de yüz yüze hizmet içi eğitime katıldıklarını ortaya çıkarma
- Sizce öğretmenler neden hem uzaktan eğitime hem de yüz yüze eğitime katıldılar?

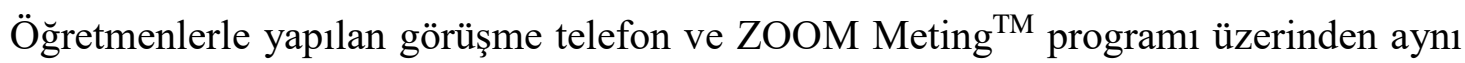
araştırmacı tarafından gerçekleştirilmiş, görüşme öncesinde öğretmenlerden ses kaydı izni alınmıştır. Görüşmeyi yapan araştırmacı görüşme sırasında notlar almış, görüşme formunda tam anlaşılmayan kısımları açıklamış ve görüşme sonunda görüşmeye katılan öğretmene ifadeleri teyit ettirilmiştir.

\section{Verilerin Analizi}

Toplanan nicel veriler SPSS $22^{\mathrm{TM}}$ programı ile analiz edilmiştir. Lisans eğitimi sırasında bilişim teknolojileri (BT) dersi alma, eğitimde teknoloji kullanımı konusunda hizmet içi eğitim kurslarına katılma durumlarıyla ilgili bilgilerinin yüzde ve frekans değerleri hesaplanmıştır. TPAB öz güvenlerini tespit etmek için verilerin ortalamaları incelenmiştir.

Alt problemlere cevap verebilmek amaciyla kullanılacak test ve analiz türlerini belirlemek için verilerin normal dağılıp dağılmadığı Kolmogorov-Smirnov testiyle incelenmiştir. Ayrıca dağılımın normal olup olmasıyla ilgili verilen kararlar histogram grafiği 
ve gövde-yaprak diyagramıyla da görsel olarak teyit edilmiştir. Kolmogorov-Smirnov normallik analiz sonuçları tablo 4 de sunulmuştur.

Tablo 4. Normallik analizi

\begin{tabular}{|c|c|c|c|c|c|c|c|}
\hline \multirow[b]{2}{*}{ Değişken } & \multirow[b]{2}{*}{ Alt değişken } & \multicolumn{3}{|c|}{ Kolmogorov - Smirnov } & \multicolumn{3}{|c|}{ Shapiro Wilk } \\
\hline & & İstatistik & Df & $p$ & İstatistik & Df & $p$ \\
\hline \multirow[t]{2}{*}{ Kursa katılım } & Evet & 0,041 & 198 & 0,2 & 0,993 & 198 & 0,454 \\
\hline & Hayır & 0,108 & 43 & 0,2 & 0,974 & 43 & 0,422 \\
\hline \multirow{2}{*}{$\begin{array}{l}\text { Lisan Eğitiminde } \\
\text { BT dersi alma }\end{array}$} & Evet & 0,046 & 148 & 0,2 & 0,989 & 148 & 0,305 \\
\hline & Hayır & 0,067 & 50 & 0,2 & 0,987 & 50 & 0,871 \\
\hline \multirow[t]{3}{*}{ Kurs tipi } & Yüz yüze & 0,081 & 31 & 0,2 & 0,986 & 31 & 0,955 \\
\hline & Uzaktan & 0,076 & 52 & 0,2 & 0,981 & 52 & 0,587 \\
\hline & $\begin{array}{l}\text { Ayr1 zamanlarda } \\
\text { uzaktan ve yüz yüze }\end{array}$ & 0,52 & 115 & 0,2 & 0,981 & 115 & 0,639 \\
\hline \multirow[t]{2}{*}{ Gönüllü Katılım } & Evet & 0,76 & 71 & 0,2 & 0,978 & 71 & 0,235 \\
\hline & Hayır & 0,56 & 127 & 0,2 & 0,994 & 127 & 0,86 \\
\hline
\end{tabular}

Verilerin normal dağılımı tespit edildikten sonra birbiriyle bağımlı olmayan ve iki grubun ortalamaları arasında anlamlı farkın olup olmadığını tespit etmek için bağımsız örneklem t testi, ikiden fazla bağımsız grubun ortalamaları arasında anlamlı farkın olup olmadığını tespit etmek için bağımsız örneklemler için faktöriyel ANOVA kullanılmıştır. ANOVA sonucunda gruplar arasında anlamlı fark çıkmadığından post hoc testlerine bakılmamıştır (Kilmen, 2015). Bu bakımdan TPAB öz güven düzeyinin öğretmenlerin üniversitede alınan BT dersi, eğitimde teknoloji kullanımı içerikli hizmet içi eğitime katılma ve katıldıkları eğitime gönüllü katılması değişkenine göre değişimini incelemek için t- testi sonuçları, ТРАВ öz güven düzeylerinin öğretmenlerin katıldıkları hizmet içi eğitimin sadece uzaktan, sadece yüz yüze veya değişik zamanlarda uzaktan ve yüz yüze olma değişkenine göre değişimini belirlemek için ANOVA analiz sonuçları incelenmiştir.

Nitel verilerin değerlendirilmesi için içerik analizi yöntemi kullanılmıştır. Görüşmenin ses kayıtları, görüşme sırasında tutulan notlarda dikkate alınarak çözümlenmiş ve MAXQDA $2020^{\mathrm{TM}}$ programına aktarılmıştır. MAXQDA 2020 programı içerisinde görüşme verileri iki araştırmacı tarafından tekrarlı olarak analiz edilmiş, kodlar ve temalar oluşturulmuştur. Kodlar oluşturulurken bir kavram veya durum ile ilgili tekrarlanan kodlar sayılarak o kodla ilgili frekans değeri tespit edilmiştir. Araştırmacılar gerçekleştirdikleri analiz sonrasında bir araya gelip kodlamalar hakkında görüş birliğine ya da ayrılığına sahip oldukları noktaları belirlemişlerdir. Araştırmacıların yaptıkları kodlamaların uyum oranı hesaplamak için Miles ve Huberman (1994) güvenirlik formülünden yararlanılmış ve ortalama olarak \%92,5 benzerlik 
YYÜ Eğitim Fakültesi Dergisi (YYU Journal of Education Faculty), 2021;18(1)1009-1041,http://efdergi.yyu.edu.tr,

bulunmuştur. Nitel verilerin sunumu sırasında çalışmaya katılan öğretmenlerin ifadelerinden örnekler sunulmuştur. Örnek cümle sunumlarında hizmet içi eğitimlere kursiyer olarak katılan öğretmenler $\mathrm{KÖ}_{1 \ldots 12}$, eğitmen olarak görev almış öğretmenler EÖ ${ }_{1 \ldots 6}$ olarak kodlanmıştır.

\section{Etik Kurul Kararı}

Bu araştırma için Atatürk Üniversitesi Sosyal ve Beşerî Bilimler Etik kurulundan (Tarih: 31.12.2020- toplantı sayısı:15) etik izin alınmıştır.

\section{Bulgular}

Bulgular iki aşamada sunulmuştur. Birinci aşamasında; çalışmaya katılan ve ölçeğe verdikleri cevapları analiz edilen 241 öğretmenin verileri tablolar halinde özetlenerek sunulmuştur. İkinci aşamada nicel verilerin değerlendirilmesinden sonra hazırlanan görüşme soruları kullanılarak eğitimde teknoloji kullanımı içerikli kurslarda görev almış 6 eğitici ve 12 kursiyer öğretmenin görüşleri kendi ifadeleriyle örneklendirilerek sunulmuştur.

\section{Üniversite eğitimi sırasında alınan BT Eğitiminin TPAB öz güvene etkisi}

Çalışmaya katılan öğretmenlerin üniversite öğrenimi sırasında aldığı BT eğitimlerin TPAB öz güvenlerinde etkilerini incelemek için bağımsız örneklem $t$ testi uygulanmıştır. Test sonuçları Tablo 5'te sunulmuştur.

Tablo 5. ТPAB Öz Güven Düzeyinin Üniversitede Alınan BT Dersi Değişkenine Göre Değişimi t- Testi Sonuçları

\begin{tabular}{|c|c|c|c|c|c|c|c|}
\hline Alt boyut & $\begin{array}{c}\text { BT } \\
\text { Ĕgitimi }\end{array}$ & $\mathbf{N}$ & $\overline{\mathbf{X}}$ & Ss & $\mathbf{t}$ & p & $\eta^{2}$ \\
\hline \multirow[t]{2}{*}{ ТРАВ } & Almış & 183 & 3,61 & 0,59 & 0,41 & 0,66 & \\
\hline & Almamış & 58 & 3,57 & 0,54 & & & \\
\hline \multirow[t]{2}{*}{ ТРВ } & Almış & 183 & 3,80 & 0,67 & 0,88 & 0,38 & \\
\hline & Almamış & 58 & 3,73 & 0,46 & & & \\
\hline \multirow[t]{2}{*}{ TAB } & Almış & 183 & 3,63 & 0,71 & 0,10 & 0,91 & \\
\hline & Almamış & 58 & 3,62 & 0,65 & & & \\
\hline \multirow[t]{2}{*}{ TB } & Almış & 183 & 3,56 & 0,71 & 2,44 & 0,01 & 0,02 \\
\hline & Almamış & 58 & 3,29 & 0,74 & & & \\
\hline
\end{tabular}

Tablo 5 incelendiğinde öğretmenlerin yalnızca TB alt boyutunda öz güven puanlarının anlamlı şekilde farklılaştığı $(t=2,44 ; p<0.05)$, görülmektedir. Öğretmenlerin TP alt boyutunda 
YYÜ Eğitim Fakültesi Dergisi (YYU Journal of Education Faculty), 2021;18(1)1009-1041,http://efdergi.yyu.edu.tr,

öz güvenlerine, lisans eğitimleri sırasında aldıkları bilişim teknolojileri eğitimin düşük-orta düzeyde $\left(\eta^{2}=0,02\right)$ etkisi olduğu görülmektedir.

\section{FATİH Projesi hizmet içi eğitimlerin TPAB Öz güvenlerine etkisi}

FATİH projesi kapsamında verilen eğitimde teknoloji kullanımı içerikli hizmet içi eğitimlerin öğretmenlerin TPAB öz güvenleri alt boyutlarında farklılaşma oluşturup oluşturmadığını tespit etmek için bağısız örneklem t testi uygulanmış ve test sonuçları tablo 6'de sunulmuştur.

Tablo 6. TPAB Öz Güven Düzeylerinin Eğitimde Teknoloji Kullanımı İçerikli Hizmet İçi Eğitime Katılma Değişkenine Göre t-Testi Sonuçları

\begin{tabular}{|c|c|c|c|c|c|c|c|}
\hline Alt boyut & $\begin{array}{l}\text { Eğitimde Teknoloji } \\
\text { Kullanımı İçerikli } \\
\text { Eğgitim }\end{array}$ & $\mathbf{N}$ & $\overline{\mathbf{X}}$ & Ss & $\mathbf{t}$ & $p$ & $\eta^{2}$ \\
\hline \multirow{2}{*}{ ТРАВ } & Katılmış & 198 & 3,66 & 0,57 & \multirow{2}{*}{ 3,39 } & \multirow{2}{*}{0,01} & \multirow{2}{*}{0,05} \\
\hline & Katılmamış & 43 & 3,33 & 0,54 & & & \\
\hline \multirow{2}{*}{ ТРВ } & Katılmış & 198 & 3,82 & 0,60 & \multirow{2}{*}{2,16} & \multirow{2}{*}{0,03} & \multirow{2}{*}{0,02} \\
\hline & Katılmamış & 43 & 3,59 & 0,70 & & & \\
\hline \multirow{2}{*}{ TAB } & Katılmış & 198 & 3,69 & 0,66 & \multirow{2}{*}{3,06} & \multirow{2}{*}{0,02} & \multirow{2}{*}{0,04} \\
\hline & Katılmamış & 43 & 3,34 & 0,77 & & & \\
\hline \multirow{2}{*}{ TB } & Katılmış & 198 & 3,55 & 0,72 & \multirow{2}{*}{2,80} & \multirow{2}{*}{0,05} & \\
\hline & Katılmamış & 43 & 3,21 & 0,66 & & & \\
\hline
\end{tabular}

Tablo 6 incelendiğinde eğitimde teknoloji kullanımı içerikli hizmet içi eğitimlere katılan öğretmenlerin özgüvenlerinin TPAB alt boyutunda $\left(t=3,39 ; p<0,05 ; \eta^{2}=0,05\right)$, TPB alt boyutunda $\left(t=2,16 ; p<0,05 ; \eta^{2}=0,02\right)$ ve TAB alt boyutunda $\left(t=3,06 ; p<0,05 ; \eta^{2}=0,04\right)$ anlaml düzeyde arttığ1, ancak TB boyutunda $(t=2,80 ; p>0,05)$ anlamlı fark oluşturmadı $\breve{g} 1$ görülmektedir. Anlamlı fark oluşan TPAB, TPB, TAB alt boyutlarındaki özgüvenlerindeki değişimin düşük- orta seviyede olduğu görülmektedir.

TB alt boyutunda hangi soruların en az ortalamaya sahip olduğunu incelenmek için sorulara verilen cevapların ortalamalarının ölçeğin ortalaması ile yüzde türünde farkı şekil 2'de sunularak görselleştirilmiştir. 


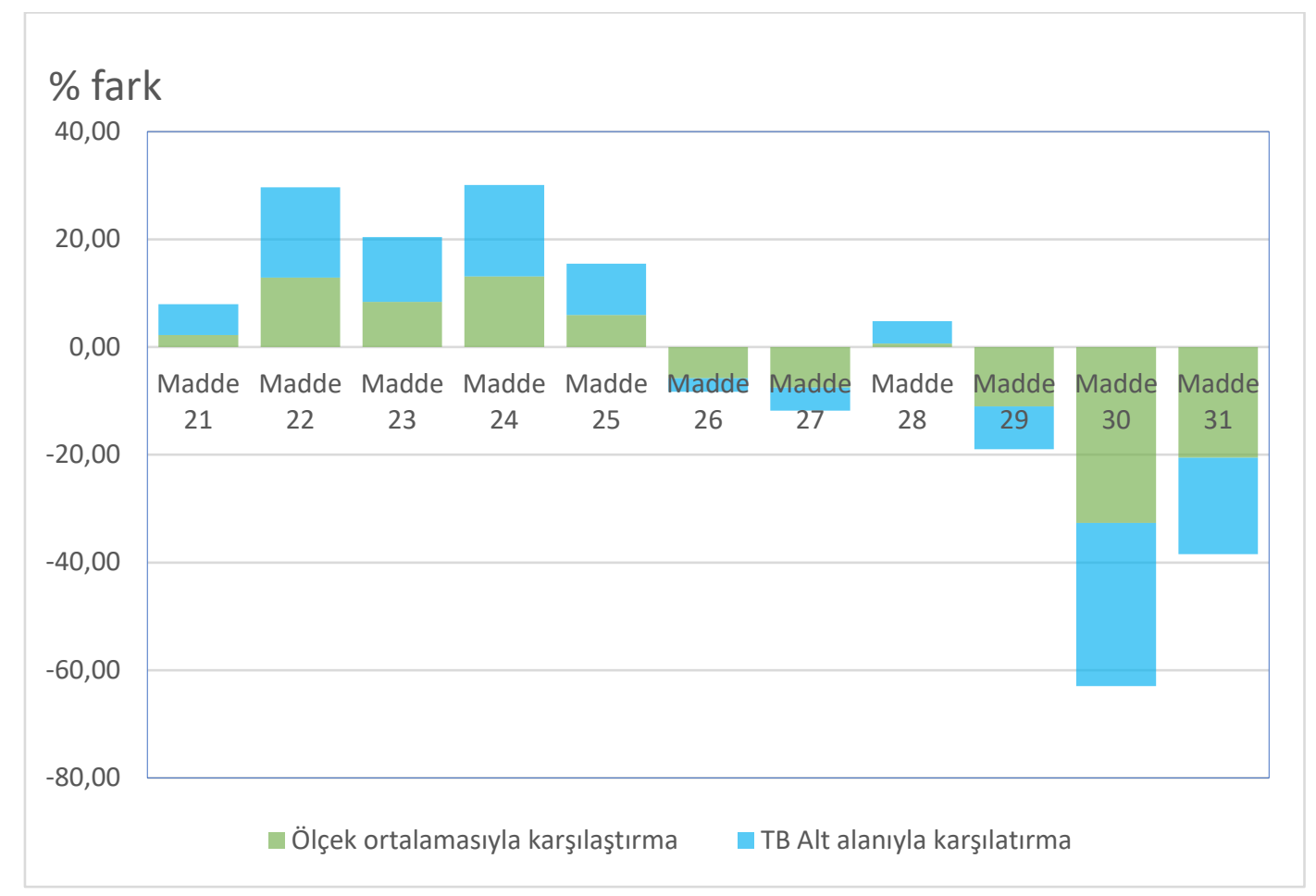

Şekil 1. TB alt boyutunda ölçek ortalaması ve soru ortalamalarının karşılaştırılması

Şekil 2 incelendiğinde özellikle ölçek madde 29: "Bir video klip oluşturmak ve düzenlemek", madde 30: "Kendi internet sitenizi oluşturmak" ve madde 31: "Web 2.0 teknolojilerini 'bloglar, sosyal iletişim platformları, podcastlar, vb.' kullanmak" ölçeğin tümünden yüzde olarak en çok negatif yönde ayrıldığı görülmektedir.

FATİH projesi hizmet içi eğitimlerinin uzaktan, yüz yüze veya her ikisi birlikte olma durumunun TBAB öz güvenin etkisi

Çalışmaya katılan öğretmenlerin TPAB öz güvenlerine, eğitimde teknoloji kullanımı içerikli hizmet içi eğitimlere yalnızca uzaktan, yalnızca yüz yüze veya değişik zamanlarda hem uzaktan hem de yüz yüze katılmış olmalarının etkilerini incelemek için bağımsız örneklem varyans analizi (ANOVA) uygulanmış, analiz sonuçları Tablo 7'da sunulmuştur.

Tablo 7. TPAB Öz Güven Düzeylerinin Öğretmenlerin Katıldıkları Hizmet İçi Eğitimin Uzaktan-Yüz Yüze Olmasına Göre ANOVA Analiz Sonuçları

\begin{tabular}{|c|c|c|c|c|c|c|c|c|c|c|}
\hline $\begin{array}{c}\text { Alt } \\
\text { boyut }\end{array}$ & Kurs Tipi & $\mathbf{N}$ & $\overline{\mathbf{X}}$ & Ss & $\begin{array}{c}\text { Varyansın } \\
\text { kaynağı }\end{array}$ & $\begin{array}{l}\text { Kareler } \\
\text { toplamı }\end{array}$ & df & $\begin{array}{c}\text { Kareler } \\
\text { ort. }\end{array}$ & $\mathbf{F}$ & $p$ \\
\hline \multirow{4}{*}{ ТРАВ } & Yüz yüze & 31 & 3,62 & 0,66 & Gruplar arası & 1,24 & 2 & 0,62 & \multirow{4}{*}{1,89} & \multirow{4}{*}{0,15} \\
\hline & Uzaktan & 52 & 3,54 & 0,54 & Gruplar içi & 63,81 & 195 & 0,32 & & \\
\hline & $\begin{array}{l}\text { İkisine de } \\
\text { katılan }\end{array}$ & 115 & 3,72 & 0,54 & Toplam & 65,05 & 197 & & & \\
\hline & Toplam & 198 & 3,66 & 0,57 & & & & & & \\
\hline \multirow{2}{*}{ ТРB } & Yüz yüze & 31 & 3,77 & 0,71 & Gruplar arası & 0,16 & 2 & 0,08 & \multirow{2}{*}{0,21} & \multirow{2}{*}{0,80} \\
\hline & Uzaktan & 52 & 3,86 & 0,67 & Gruplar içi & 73,03 & 195 & 0,37 & & \\
\hline
\end{tabular}


YYÜ Eğitim Fakültesi Dergisi (YYU Journal of Education Faculty), 2021;18(1)1009-1041,http://efdergi.yyu.edu.tr,

\begin{tabular}{|c|c|c|c|c|c|c|c|c|c|c|}
\hline & $\begin{array}{l}\text { İkisine de } \\
\text { katılan }\end{array}$ & 115 & 3,82 & 0,55 & Toplam & 73,19 & 197 & & & \\
\hline & Toplam & 198 & 3,82 & 0,60 & & & & & & \\
\hline & Yüz yüze & 31 & 3,73 & 0,59 & Gruplar arası & 0,19 & 2 & 0,9 & & \\
\hline & Uzaktan & 52 & 3,64 & 0,64 & Gruplar içi & 87,83 & 195 & 0,45 & & \\
\hline TAB & $\begin{array}{l}\text { İkisine de } \\
\text { katılan }\end{array}$ & 115 & 3,71 & 0,70 & Toplam & 88,02 & 197 & & 0,21 & 0,80 \\
\hline & Toplam & 198 & 3,69 & 0,6 & & & & & & \\
\hline & Yüz yüze & 31 & 3,42 & 0,77 & Gruplar aras1 & 1,24 & 2 & 0,62 & & \\
\hline & Uzaktan & 52 & 3,66 & 0,60 & Gruplar içi & 102,97 & 195 & 0,52 & & \\
\hline ТВ & $\begin{array}{l}\text { İkisine de } \\
\text { katılan }\end{array}$ & 115 & 3,54 & 0,76 & Toplam & 104,21 & 197 & & 1,17 & 0,31 \\
\hline & Toplam & 198 & 3,55 & 0,72 & & & & & & \\
\hline
\end{tabular}

Tablo 7 incelendiğinde öğretmenlerin katıldıkları eğitimde teknoloji kullanımı içerikli hizmet içi eğitimlere; yalnızca uzaktan katılmış olma, yalnızca yüz yüze katılmış olma veya her iki kursa farklı tarihlerde katılmış olma durumunun TPAB, TPB, TAB ve TB alt boyutlarında özgüvenlerinde anlamlı fark ( $p>0,05)$ oluşturmadığı görülmektedir.

\section{Hizmet içi eğitimlere gönüllü katılma durumunun TPAB öz güvenine etkisi}

Çalışmaya katılan öğretmenlerin, eğitimde teknoloji kullanımı içerikli hizmet içi eğitimlere katılımın gönüllü olup olmamasına göre TPAB öz güvenlerine etkilerini incelemek için bağımsız örneklem t testi uygulanmış ve test sonuçları Tablo 8'de sunulmuştur.

Tablo 8. TPAB Öz Güven Düzeylerine Öğretmelerin Katıldıkları Eğitime Gönüllü Katılması Değişkenine Göre Bağımsız Örneklem t Testi Sonuçları

\begin{tabular}{clcccccc}
\hline Alt boyut & Katılım Gönüllü & $\mathbf{N}$ & $\overline{\mathbf{X}}$ & Ss & $\mathbf{t}$ & $\mathbf{p}$ & $\mathbf{\eta}^{\mathbf{2}}$ \\
\hline \multirow{2}{*}{ ТРАВ } & Evet & 71 & 3,96 & 0,50 & \multirow{2}{*}{6,14} & 0,00 & 0,161 \\
& Hayır & 127 & 3,48 & 0,53 & & & \\
\hline \multirow{2}{*}{ ТРB } & Evet & 71 & 4,06 & 0,48 & \multirow{2}{*}{4,59} & 0,00 & 0,10 \\
& Hayır & 127 & 3,69 & 0,63 & & & \\
\hline \multirow{2}{*}{ TAB } & Evet & 71 & 3,93 & 0,61 & \multirow{2}{*}{3,87} & 0,00 & 0,07 \\
& Hayır & 127 & 3,56 & 0,66 & & & \\
\hline \multirow{2}{*}{ TB } & Evet & 71 & 3,87 & 0,63 & \multirow{2}{*}{4,80} & 0,00 & 0,11 \\
& Hayır & 127 & 3,38 & 0,71 & & & \\
\hline
\end{tabular}

Tablo 8 incelendiğinde eğitimde teknoloji kullanımı içerikli hizmet içi eğitimlere gönüllü katılımın öğretmenlerin TPAB özgüvenlerinde $\left(t=6,14 ; p<0,05 ; \eta^{2}=0,16\right)$, ТРВ özgüvenlerinde ( $\left.t=5,59 ; p<0,05 ; \eta^{2}=0,10\right)$, TAB özgüvenlerinde $\left(t=3,87 ; p<0,05 ; \eta^{2}=0,07\right)$, ТВ 
özgüvenlerinde $\left(t=4,80 ; p<0,05 ; \eta^{2}=0,11\right)$ gönüllü katılım lehine anlamlı fark oluşturduğu ve gönüllü olarak kursa katılımın etkisi orta -yüksek düzeyde olduğu görülmektedir.

Eğitimde teknoloji kullanma içerikli hizmet içi eğitimlere katılmış olmanın öğretmenlerin TB öz güvenleri üzerine neden etkisiz olduğuna dair öğretmen görüşleri

Eğitim teknolojileri içerikli hizmet içi eğitim kurslarına katılmış olmak fen alanı öğretmenlerinin TPAB, TPB, TAB boyutlarındaki özgüvenlerini artırmıştır, ancak TB alt boyutundaki özgüvende anlamlı değişime neden olmamıştır. Bu durumun nedenlerini ortaya çıkarmak amacıyla kurslarda eğitim veren ve eğitim alan öğretmenlere elde edilen sonuçlar açıklanmış ve nedeni hakkında düşünceleri sorulmuştur. Öğretmenlerle yapılan görüşmeden elde edilen kodlar Şekil 3’de kod-matrix olarak görselleştirilerek sunulmuştur.

\begin{tabular}{|c|c|c|c|c|}
\hline Kod Sistemi & Uzaktan Eğitim Katılımcı & Uzaktan ve Yüz Yüze E.Katıl... & Eğitici Öğretmen & TOPLAM \\
\hline$\nabla$ C Teknolojik Bilgi & & & & 0 \\
\hline$\odot$ Yetersiz kurs süresi & & - & $=$ & 10 \\
\hline Kullanilmayan bilgi & & - & - & 10 \\
\hline$\odot$ Kursa ihtiyaç yok & & - & - & 4 \\
\hline$\odot$ içerik zayıf & & $\square$ & $\square$ & 36 \\
\hline Farklı seviyede kursiyer & & - & - & 3 \\
\hline$\Sigma$ TOPLAM & 16 & 22 & 25 & 63 \\
\hline
\end{tabular}

Şekil 2. Teknolojik bilginin değişiminde eğitimde teknoloji kullanımı kurslarının neden etkisiz olduğuna dair öğretmen görüşleri

Şekil 3 incelendiğinde görüşmeye katılan öğretmenler teknolojik bilgi bakımından "kurs içeriğinin zaylf olma” kodunu en sık tekrarladıkları $(f=36)$ görülmektedir. Özellikle sadece uzaktan eğitime katılan öğretmenler teknolojik bilgi konusundaki eksikliği en fazla ifade eden grup olmuştur. Yüz yüze eğitime katılan veya eğitici olarak görev alan öğretmenlerde teknolojik bilgi boyutunda kurs içeriklerinin yetersiz olduğunu sıklıkla ifade etmelerinin yanında kurs süresinin yetersiz olması ve kursta öğretilen içeriklerin daha sonra kullanılmaması sonucunda bu konudaki öz güvenlerinin değişmemesine neden olabileceğini ifade etmişlerdir. Görüşmeye katılan öğretmenlerin cevaplarından bir kısmı aşağıda sunulmuştur;

$\mathrm{KÖ}_{3}$ : 'Kurs süresi normalde 25 saat olmasına ră̆men biz ancak 15 saat yapabildik, kursların akşam saatlerinde olması, eğitim öğretimin devam ettiği günlerde olması çok yorucu, bizde eğitimcide daha fazlasını kaldıramıyorduk.

$\mathrm{KÖ}_{4}$ : 'Kursta video düzenleme konusunda içerik vardı. Ancak video düzenlemeyi sonradan hiç kullanmadım. Özellikle alanımız itibari ile pek çok video içerik var. Bunlarl rahatlıkla bulup kullanabiliyoruz. Uğraşmak istemiyoruz. Teknolojinin en büyük handikabı hazırcılı̆̆a alıştırması, bunun sonucu ögrenilen bu bilgiler zamanla kayboluyor.' 
Eğitimde teknoloji kullanımı içerikli hizmet içi eğitimlerin uzaktan veya yüz yüze olmasının TPAB öz güveninde anlamlı fark oluşturmaması hakkında öğretmen görüşleri

Hizmet içi eğitimlerin yüz yüze veya uzaktan olmasının TPAB öz güveninde önemli bir fark oluşturmama nedenini incelemek amacıyla, görüşmeye katılan öğretmenlere uzaktan eğitim ve yüz yüze eğitim konusunda karşılattıkları sorun ve önerileri sorulmuştur. Yüz yüze eğitim konusunda görüşleri Şekil 4, uzaktan eğitim hakkındaki görüşleri Şekil 5’te, bu kurslar hakkındaki genel önerileri Şekil 6 'te kodlanarak sunulmuştur.

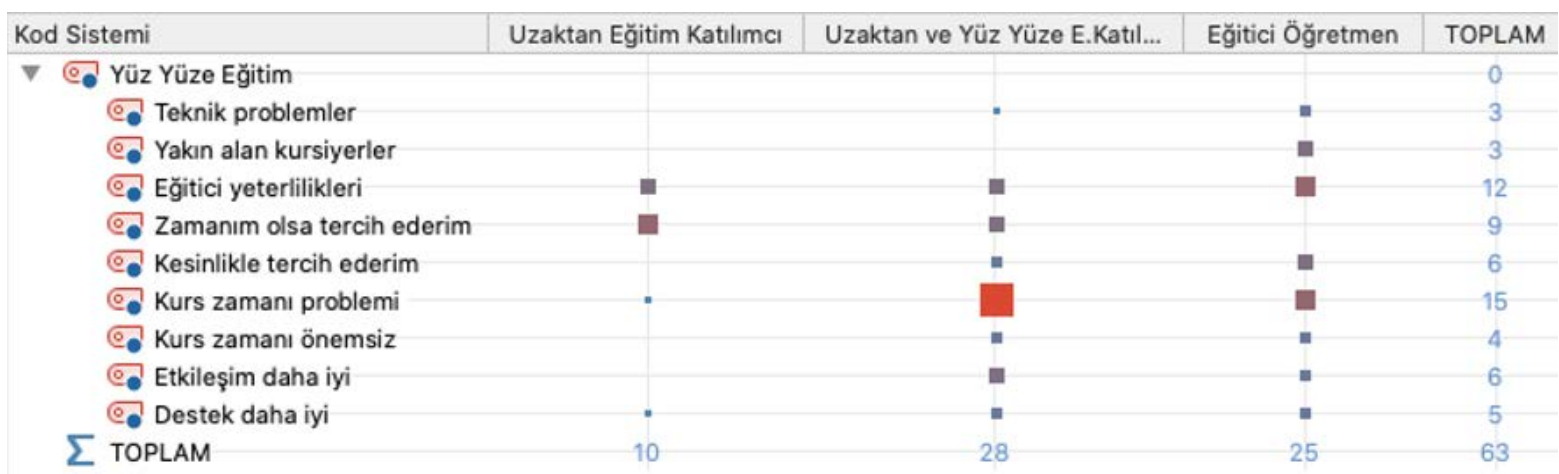

Şekil 3. Yüz yüze eğitim konusunda öğretmen görüşleri

Eğitimde teknoloji kullanımı içerikli yüz yüze hizmet içi eğitimler hakkında öğretmenlerle yapılan görüşmelerden elde edilen kodların sunulduğu şekil 4 incelendiğinde eğitimde teknoloji kullanımı içerikli, yüz yüze gerçekleştirilen hizmet içi eğitimde "kurs zamanı problemin” en sık tekrarlanan $(f=15)$ kod olduğu görülmektedir. Kurs zamanı problemi kodu için iki öğretmen ifadesi aşağıda sunulmuştur.

KÖ: Öğretmenin zamanı varsa yüz yüze eğitim öğrenme konusunda çok aktif ve faydalı. Bizim kurslar akşam saatlerindeydi. Yorgunduk, bazen ders çıkışı kursa katılmak çok zor oluyordu, kurs içeriği güzel eğlenceli, verimli olsa bile bir an önce bitsin havasindaydı"”

$\mathrm{EO}_{2}$ : “Kursların akşam saatlerinde olması da ĕgitimleri çok olumsuz etkiliyor. Katılımcılar zaten yorgun istenilen verim olmuyor 5 saatlik kurs ancak 3 saat yapılabiliyor.

Yüz yüze kurslarda sorun olarak ifade edilen diğer bir husus "eğitici yeterlilikleri" olarak kodlanmıştır ( $f=12)$; eğitici, yüz yüze kurs katılımcısı ve uzaktan eğitim katılımcısı öğretmenlerce değinilen bir sorun olduğu görülmektedir. Eğitici yeterlilikleri konusunda görüşmeye katılan öğretmenlerin verdikleri cevaplardan örnekler aşağıda sunulmuştur.

KÖ 6: “İçerik değil ama ögreticinin üslubu çok önemli. Yapılışşekli değişebilir, içerik güncellene bilir ancak ĕgitimcinin o içeriği nasıl işleyeceği çok öneli bir konu” 
KÖ8: “Yüz yüze eğitime katılmak isterim. Daha verimli olacağını düşünüyorum. Bunun yanında eğitimciyi de ben seçebilmeliyim. Aynı okuldan aynı isimli kurslara giden arkadaşlarım farklı ĕgitimcilerle karşılaştılar, bir kısmı çok iyi öğrendi. Bazıları ise hiç fayda görmediklerini, vakit kaybı olduğunu söylüyorlardı. Aynı kursa katılan kişilerden benzer tepkiler alınması tesadüfi olamaz. Yüz yüze eğitimde takıldiğım konuyu sorabilirim. Ancak benzer şartlarda yine uzaktan eğitimi tercih ederim.”

$\mathrm{KÖ}_{2}$ : “Ĕgitim veren öğretmen çok iyi yetişmiş olmall, öğretmeye çalıştı̆̆ $\breve{g ̆}_{l}$ konuları öncelikle kendisi aktif olarak sinıf ortamında test etmiş olmall."

Yüz yüze eğitimlerde “destek daha iyi” $(f=5)$ ve "etkileşim daha iyi” ( $f=6)$ kodlarının hem katılımcı hem de eğiticiler tarafından vurgulandığı görülmektedir. Özellikle eğiticiler yakın branş veya aynı branşlardan öğretmenlerin kurslarda bulunmasının, kursun daha verimli geçmesine neden olacağını ifade etmişlerdir. Bu duruma örnek olarak;

EӦ 2 : Ögretmenlerin branşlara göre ayrılmış olmaları daha faydalı kurs verilmesini sağlıyor. Örnek verirken alanları ile ilgili örnekler verebiliyoruz. Aynı anda sınıfta birden fazla branş olduğunda birine verdiğin örnek veya anlattı̆̆ın araç diğerinin hiç ilgisini çekmeyebiliyor. Örneğin Geogerbra anlatıyoruz Türkçe öğretmeni sıkılıyor. Bu sebeple branşlara göre ayrılmış şekilde olması daha faydalı olacaktır.

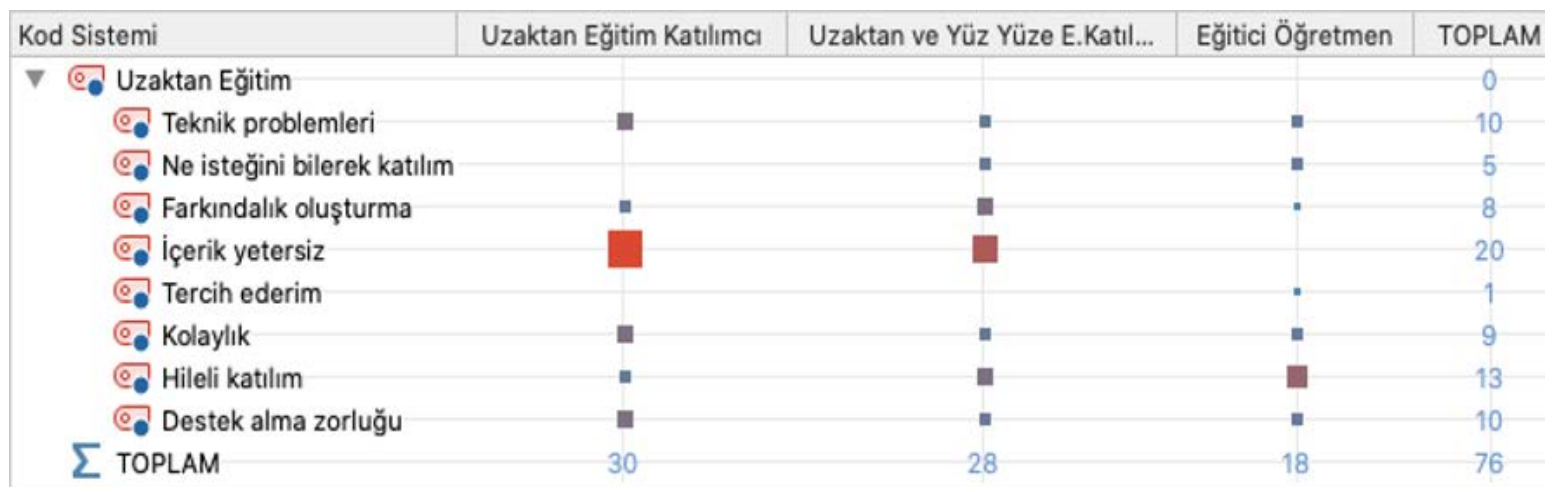

Şekil 4. Uzaktan eğitim konusunda öğretmen görüşleri

Eğitimde teknoloji kullanımı içerikli uzaktan hizmet içi eğitimler konusunda öğretmenlerle yapılan görüşmelerden elde edilen kodların görselleştirildiği şekil 5 incelendiğinde; en sık tekrarlan kodun "içerik yetersizliği”" $(f=20)$, daha sonra "hileli katılım" $(f=13)$, “destek alama zorluluğu" $(f=10)$, "teknik problemler" $(f=10)$ kodlar1 olduğu görülmektedir. İçerik yetersizliği ve destek alama zorluğu kodlarıyla ilgili öğretmen ifadelerinden örnekler aşağıda sunulmuştur;

$\mathrm{KÖ}_{7}$ “Uzaktan ĕgitimde yalnızca ĕgitimde teknoloji kullanımı içerikleri vardı. Örneğin etkileşimli tahtada çıkabilecek sorunların konusunda geniş öğretici bir içerik yoktu. 
Benzer içerikli yüz yüze eğitime katılmış arkadaşlarım etkileşimli tahta da çıkabilecek sorunları öğrenmişti. Bende onlardan ögrendim.”

KÖ9 “Uzaktan eğitimde en büyük zorluk destek alama konusunda, yüz yüze eğitim kadar destek noktası yok. Son zamanlarda EBA üzerindeki gruplarda destek sağlamak için çeşitli form yapıları var. Ancak bu doğrudan eğiticiden destek alma kadar faydalı olamiyor"

“Hileli katılım” ( $f=13)$ olarak kodlanan durum; uzaktan eğitimler konusunda kursun kontrolünün yetersiz olması sonucu katılımcı öğretmenler tarafından kursun izlenmeden ve kurs sonu sınav cevaplarının bir şekilde elde edildiği yönünde ifadeler en sık yüz yüze kurs eğitimcileri olmak üzere bütün gruplarda ifade edilmiştir. Bu durumla ilgili örnek öğretmen cevabi;

KÖ ${ }_{5}:$ “Uzaktan eğitimin ancak \%30-40 ‘ hakkı ile yapılıyor. İçerik izlenmeden geçiliyor. Sorular internetten bulunuyor. Elbette hakkı ile yapanlar var ancak bunlar azınlıkta. Bazı öğretmenler bu tip işleri zaman kaybı olarak görüyor”

“Farkındalık oluşma” kodu ( $f=8)$; uzaktan eğitim yöntemi ile gerçekleştirilen kurslar sayesinde öğretim sürecinde kullanabileceği yeni teknolojiler hakkında farkındalık oluştuğunu şeklinde öğretmenlerce açıklanmıştır. Bu koda örnek öğretmen açıklaması;

KÖ${ }_{10}:$ "Evimin rahatlı̆̆ında kursa katıldım. Diğer bazı konuları okuldaki arkadaşlarla hallettim. Aslında kursun en büyük faydası farkındalık oluşturması oldu. Bir şekilde ihtiyacın olduğunda bu da vardı deyip üzerine gidilince çözülebiliyor.”

\begin{tabular}{|c|c|c|c|c|}
\hline Kod Sistemi & Uzaktan Eğitim Kat... & Uzaktan ve Yüz Yüze E.Ka... & Eğitici Öğret... & $\begin{array}{c}\text { TOPLAM } \\
0\end{array}$ \\
\hline ๑ Aşamalı ve ihtiyaca göre eğitimler & & घ & $=$ & 11 \\
\hline Hibrit kurslar & " & $\cdot$ & 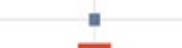 & 11 \\
\hline @ Motivasyon ve gönüllü katılım & : & - & 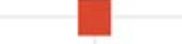 & 31 \\
\hline$\sum$ TOPLAM & 23 & 27 & 37 & 87 \\
\hline
\end{tabular}

Şekil 5. Kurslar hakkında genel sorun ve öneriler

Eğitime teknoloji kullanımı içerikli hizmet içi eğitimler hakkında öğretmenlerin genel sorun ve önerilerinin özetlendiği şekil 6 incelendiğinde en öne çıkan kodun "motivasyon ve gönüllü katılım” kodu ( $f=31)$ olduğu görülmektedir. Motivasyon ve gönüllü katılım kodu özellikle yüz yüze eğitimlerde eğitici olarak görev alan öğretmenlerce dile getirildiği görülmektedir. Motivasyon ve gönüllü katılım koduyla ilgili görüşmeye katılan öğretmenlerin cevaplarında örnekler; 
EÖ4: “Öğretmen kursa isteyerek, ögrenme gayesi ile geliyorsa hem ona hem bize çok eğlenceli, verimli bir kurs oluyor, aksi durumda kursiyerde, bizde zorlaniyoruz."

$\mathrm{KO}_{2}:$ “Talebe kavramı talep eden kavramından geliyor, birisinin bir talebi yoksa siz ona zorla bir şey öğretemezsiniz. Öncelikle ögrrenecĕ̆i konu için özendirilmeli”

“Zengin kurs içerikleri” kodunun $(f=26)$, başta uzaktan eğitime katılan öğretmenler olmak üzere tüm gruplarda dile getirildiği görülmektedir. “Aşamalı ve ihtiyaca göre eğitimler” kodu ( $f=11)$, kursların bir kısmının uzaktan bir kısmının yüz yüze yapılması konusundaki önerler için kodlanan “hibrit kurslar” kodu $(f=11)$ da görüşmelerde sıklıkla tekrarlanan öneriler arasında yer almaktadır. Bunlarla beraber “değişim ajanı” olarak kodlanan okul içinde eğitim teknolojilerini aktif olarak kullanan ve diğer öğretmenlerin de bu teknolojileri öğrenmesi konusunda özendiren öğretmenler hakkındaki ifade de her grup içinde görülmektedir. Bu kodlarla ilgili görüşmeye katılan öğretmenlerin cevaplarından örnekler;

EÖ: Okulda teknolojiyi iyi kullanan, ögrretim sürecinde işine yarayan öğretmenler olunca diğerleri onları takip ediyor. Her okulda bu şekilde birini tespit edip bunlarla yaygınlaştırma yapılabilir. Öğretmen kursa daha gönüllü gelecektir. Gönüllü olarak geldiği içinde başarıl olacaktır. Bu uzaktan ĕgitimler içinde geçerli bu şekilde yetenekli bilişim teknolojileri rehber ögretmenlerin olduğu okullarda bu konu ile çok karşılattım. Bu bilgi işe yarıyor, ögretim sürecini zevkli, kolay hale getiriyor algısı bir şekilde ögretmenlerin bu alana yönelmesine neden oluyor.

KÖ ${ }_{1}:$ “Okullardaki diğer ögretmenlerden özellikle aynı branştaki öğretmenlerde çok etkileniyor. Bir öğretmenin kursta öğrendikleri işine yarlyor ve bunu gösteriyorsa diğeri de o kursa katılmak istiyor."

Çalışmaya katılan pek çok öğretmen içerikleri benzer olmasına rağmen hem yüz yüze hem de uzaktan eğitime katılma nedenleri hakkında görüşme bulguları Şekil 7 sunulmuştur.

\begin{tabular}{|c|c|c|c|c|}
\hline Kod Sistemi & Uzaktan Eğitim Katll... & Uzaktan ve Yüz Yüze E.... & Eğitici Öğretmen & TOPLAM \\
\hline \multicolumn{5}{|l|}{$\nabla$ Her iki kursada katılma } \\
\hline ๑ Pekiştirme-ilgi & & $=$ & & 1 \\
\hline Uzaktan eğitimden verim alamama & & & a & 2 \\
\hline @isteksiz-zorlama & & $\mathbf{a}$ & & 8 \\
\hline$\sum$ TOPLAM & 0 & 4 & 7 & 11 \\
\hline
\end{tabular}

Şekil 6. Öğretmenlerin hem uzaktan hem de yüz yüze eğitime katılma nedenleri

Şekil 7 incelendiğinde öğretmenlerin eğitimde teknoloji kullanımı içerikli hizmet içi eğitimlerden benzer içerikli olmalarına rağmen hem uzaktan hem de yüz yüze eğitimlere ayrı ayrı zamanlarda katılma nedenlerinden en sık ifade edilen “isteksiz-zorlama” kodu ile kodlanan okul idareleri tarafından öğretmenlerin yanlış yönlendirilmesi veya zorlaması ile kursa 
katılması olduğu görülmektedir $(f=8)$. Bundan daha az olarak önce uzaktan eğitimde katılmış ancak uzaktan eğitimde yeterli verim alamama ve eğitimde teknoloji kullanımı konusunda ilgisinden dolayı pekiştirme amacıyla kursa katılma diğer ifade edilen nedenlerdendir.

\section{Tartışma ve Sonuç}

Çalışmanın amacı özellikle FATi்H projesi sayesinde aktif görevde olan öğretmenlerin büyük çoğunluğunun katılımı sağlanan eğitimde teknoloji kullanımı içerikli hizmet içi eğitimlerin ТРАВ öz güvenlerine etkilerini derinlemesine incelemektir. Bu bölümde nicel olarak elde edilen veriler ve hizmet içi eğitimlerde eğitmen ve katılımcı öğretmenlerin görüşlerinin harmanlanarak tartışılmaya çalışılmıştır.

Öğretmenlerin üniversite eğitimleri sırasında aldıkları bilişim teknolojileri eğitimleri yalnızca teknolojik bilgi alt boyutunda öz güvenlerini artırmıştır. Ancak üniversite eğitimleri sırasında alınan derslerin eğitime teknolojiyi entegre etme konusunda her zaman başarılı olamayabilir (Wang, Schmidt-Crawford ve Jin, 2018). Bu eğitimlerin branşlarına yönelik olmaması sonucunda alan bilgisi, pedagojik bilgi ve tümünün etkileşimi sonucu oluşan teknolojik pedagojik alan bilgisi öz güvenlerine katkısı sınırlı kalmış olabilir. Bu sonuç, alan yazında Öçal ve Şimşek (2017)'in üniversitede verilen eğitimlerin pratiğe dönük olması gerektiğini, Tatli ve Akbulut (2017)'un öğretmen adaylarının üniversite eğitimi sırasında öğrendiği teknolojik bilgileri öğretim sürecine yeterince entegre edemediği yönündeki bulguları ile uyumludur. Yine Angeli ve Valanides (2009), Kay (2006), Polly, Mims, Shepherd ve Inan (2010), Tondeur, Roblin,Van-Braak, Fisser ve Voogt (2013) öğretmen adaylarının teknolojiyi eğitime entegre etme konusunda çok fazla sorunları olduğu yönündeki bulguları da bu durumu desteklemektedir. Odaklanılması gereken husus öğretmen adaylarının teknolojiyi nasıl kullandıkları değil, teknolojiyi eğitim öğretim için nasıl kullandıkları olmalıdır (Tondeur vd. 2013). Sadece bilgi tabanlarının (içerik bilgisi, pedagojik bilgi, teknolojik bilgi) geliştirilmesi öğretmenlerin TPAB'larini geliştirmek için yeterli değildir, özel olarak TPAB konusunda eğitimler verilmelidir (Padmavathi, 2017). Son yıllarda üniversite eğitimi sırasında verilen BT eğitimlerinin alana özel olarak verilmesi TPAB öz güveninin TB boyutu dışında diğer alt boyutlarının da geliştirebilir, ancak çalışmaya katılan öğretmenlerin mezun dolduğu dönemlerinde üniversitedeki BT eğitimlerin alana özgü olmaması çalışmada elde edilen sonucun nedeni olarak açıklanabilir. Bunun yanında teknolojinin sürekli ilerlediği, değiştiği ve dönüştüğü günümüz için öğretmenlerin üniversite öğretimleri sırasında aldıkları eğitimlerin yetersiz gelmesi normal olarak değerlendirilebilir, ancak buradaki asıl sorun bu eğitimleri alan 
öğretmenlerin değişme ayak uyduramamalarıdır. Bu bakımdan, üniversitede verilen eğitimler, öğretmenlerin kendilerini geliştirmeleri konusunda teşvik edici nitelikte olmalıdır.

FATİH projesi kapsamında öğrenmelerin eğitimde teknoloji kullanımı içerikli kursa katılmış olması, TPAB, TAB, TPB alt boyutunda öğretmenlerin öz güvenlerini olumlu yönde etkilemiştir. Alan yazında Bağdiken ve Akgündüz (2018), Bal ve Karademir (2013), Kocaoğlu ve Akgün (2015), Özkara vd. (2018) hizmet içi eğitime katılan öğretmenlerin kendilerini TPAB yönünden daha öz güvenli hissettiklerini tespit etmiştir. Bu çalışmalardan farklı olarak çalışmamızda eğitimde teknoloji kullanımı içerikli hizmet içi eğitimlerin TB boyutlarda önemli bir etkisi tespit edilememiştir. Bu durumunun nedenleri kurs içeriklerinin teknolojik bilgi bakımından yetersizliğgi, teknolojik bilgi olarak sunulan video düzenleme gibi konuların öğretmenlerin hazır materyal kullanmaları nedeni ile daha sonra kullanmamalarından dolayı unutulması olabilir. Bu durum Tatli ve Akbulut (2017) çalışmasında; öğretmenlerin hazır ders materyalleri kullanmaları ve bu konuda alışkanlık kazanmalarının kendi içerik üretme yeterliklerini körelteceği şeklinde ifade etmiştir. Yine diğer önemli bir sorunda yetersiz kurs süresidir. Alan yazında yapılan çalışmalarda kurs zamanın uygun olmaması ve sürenin yetersiz olduğu konusunda veriler bulunmaktadır (Günbayı ve Taşdöğen, 2012; Limon, 2014; Sarıtepeci vd., 2016). Özellikle yüz yüze kursların akşam saatlerinde olması nedeni ile planlanan süreden daha kısa olarak gerçekleştirilmesi planlanan içeriklerin öğretimi için zamanın yetersiz kalmasina neden olabilir.

Hizmet içi eğitime sadece uzaktan veya sadece yüz yüze katılan öğretmenlerin TPAB öz güvenlerinde fark bulunmamaktadır. Uzaktan eğitimde içerik ve etkileşim daha az olmasına rağmen öğretmenlerin TPAB öz güvenleri üzerinde yüz yüze eğitimden geri kalmaması dikkat çeken bir durumdur. Özellikle yüz yüze eğitimlerde kurs zamanın akşamları olması nedeni ile sürenin etkili olarak kullanılamaması bu duruma neden olmuş olabilir. Kurs sürelerinin yetersizliği ve kurs zamanı ile ilgili bulgular Günbayı ve Taşdöğen, (2012) çalışması ile benzerdir. Bu konuda diğer bir etken de eğitimci yetersizliği olabilir, kurs eğitimcilerinin her şeyden önce öğretimini gerçekleştirdiği içeriği kendi öğretmenlik sürecinde de uygulayan eğitimcilerden seçilmelidir. Keleşoğlu ve Yiğit (2017) hizmet içi eğitimlerde görevli eğitimcilerin en az doktora derecesinde, alanına hakim öğretmenlerden seçilmesi önermektedir. Ayvacı vd. (2014) çalışmasında genel hizmet içi eğitimlerde eğitimcilerin sınıf deneyimine sahip olması, eğitimde teknoloji kullanımı konusunda hizmet içi eğitimlerde daha da önemli olduğunu ifade etmiştir. Eğitimcilerin özellikle iletişim becerilerinin yüksek olması (Günbayı ve Taşdöğen, 2012), içeriği öğretirken öğretmenlerin alanlarında bu bilgileri nasıl kullanacağı 
konusunda örnekler sunabilmesi, hizmet içi eğitimlerin amacına ulaşması için önemli katkı sunabilir. Eğitimi verilen konularda katılımcı öğretmenlerin tecrübe ve fikir paylaşımı yapması açısından yüz yüze eğitime katılan öğretmenlerin aynı branştan olması avantaj olarak kullanılabilir. Bu durum alan yazında FATİH projesi kurslarının alana özel olması gerektiği hususunda Aktas vd. (2014); Öçal ve Şimşek (2017) çalışmalarında da vurgulanmıştır.

Uzaktan eğitim olarak gerçekleştirilen hizmet içi eğitimlerde karşılaşılan zorluklar; içeriğin yetersiz olması, destek alma zorluğu, teknik problemlerdir. Benzer bulgular Limon, (2014) çalışmasında da yer almaktadır. Yine uzaktan hizmet içi eğitim sonunda ölçme değerlendirmenin zorluğu, eğitim sürecinde veya eğitim sonunda kontrol mekanizmalarının yetersizliği nedeni ile hileli katılım sorunları da bulunmaktadır. Bununla birlikte öğretmenlerin yeni teknolojiler konusunda farkındalık oluşturması, istediği mekandan kursa katılabilmesi ve zaman serbestliği uzaktan eğitimi tercih edilebilir hale getirmektedir (Limon, 2014; Taşlıbeyaz ve Karaman, 2014) ancak, yüz yüze eğitimin şartlarının uygun olması halinde daha çok tercih edilebilir.

Uzaktan eğitimin zayıf yönleri olarak görülen etkileşim, destek alma zorluğu yüz yüze hizmet içi eğitimin üstün yönlerini oluşturmaktadır. Eğitimde teknoloji kullanımı konusundaki hizmet içi eğitimlerin uygulamalı ve etkileşimli olması önemlidir (Demirer ve Dikmen, 2018). Yüz yüze hizmet içi eğitimler öğretmenlerin belirli zamanlarda, belirli bir mekânda bulunmasını gerektiren eğitimlerdir. Bu durum hem zaman hem de hizmet içi mekanlarının oluşturulması için maddi kaynak kullanılmasını gerektirmektedir. Sadece yüz yüze eğitim veya sadece uzaktan eğitim yerine öğretmenlerin hizmet içi eğitim içeriğinin teorik kısımlarını uzaktan eğitimle alacağı, uygulamalı kısımlarda yüz yüze eğitim gerçekleştirebileceği bir model; zaman ve kaynak israfını önleyebilir. Bunun yanında hizmet içi eğitime katılan öğretmenlerin ön yeterliliklerine uygun, ihtiyaçlarını karşılayabilecek şekilde hizmet içi eğitimlerin aşamalı olarak planlanması, kursiyerler kabul edilirken aynı branştan öğretmenlerin bir araya getirilmesi hizmet içi eğitimlerin amaçlarına erişmesi için faydalı olabilir.

Hizmet içi eğitimleri öğretmenlerin tamamen kendi istekleri ile katılımları bütün alt boyutları ile TPAB öz güvenlerini olumlu etkilemektedir. Bu bakımdan hizmet içi eğitime öğretmenleri zorlayıcı yöntemlerle değil, ikna ederek ve eğitimin kendileri için ihtiyaç olduğunu hissettirerek katılımların sağlanması TPAB öz güven gelişimi için önemli olduğu düşünülmektedir. Nitekim Günbayı ve Taşdöğen (2012) çalışmalarında hizmet içi eğitimlerde amaca ulaşmayı etkileyen en önemli etmenin eğitime gönüllü katılım olduğunu vurgulamıştır. $\mathrm{Bu}$ amaçla hizmet içi eğitimlere katılan öğretmenlere hizmet puanı veya uzman öğretmenlik 
YYÜ Eğitim Fakültesi Dergisi (YYU Journal of Education Faculty), 2021;18(1)1009-1041,http://efdergi.yyu.edu.tr,

gibi kariyer basamaklarında katkısı olabilecek puanlar verilebilir. Yine öğretmenlerin kursa katılımı için zaman veya kurs mekanlarının çekici olması da fayda sağlayabilir. Daha iyisi ise uygun ortamlar sağlandıktan sonra hizmet içi eğitimin öğretmene kazandıracakları fark ettirilerek ikna edilmesi olacaktır.

\section{Makalenin Bilimdeki Konumu}

Matematik ve Fen Bilimleri Eğitimi Bölümü/Fen Bilgisi Eğitimi

\section{Makalenin Bilimdeki Özgünlüğü}

Alan yazımda öğretmen adaylarının TPAB yeterlilikleri konusunda çalışmalar yoğunluktadır, öğretmenlerin TPAB öz güvenleri geliştirmek amaçlı hizmet içi eğitimler konusunda çalışmalarda alan yazında rastlanmaktadır. Ancak eğitimde teknoloji kullanımı içerikli hizmet içi eğitimlerin uzaktan veya yüz yüze olması, öğretmemelerin katılımının gönüllü olmasının TPAB öz güven düzeyine etkileri konusunda yeterli çalışma olmadığı tespit edilmiştir. Bu nedenle eğitimde teknoloji kullanımı içerikli hizmet içi eğitimlerin uzaktan veya yüz yüze olması, katılımın gönüllü veya gönülsüz olması boyutları incelemeye alınmıştır. Çalışma sonuçları gelecekte gerçekleştirebilecek eğitimde teknoloji kullanımı içerikli hizmet içi eğitimlerin daha etkin ve faydalı olması amacıyla kullanılabilir. 


\section{Kaynaklar}

Akgün, E., Y1lmaz, E. O., \& Seferoğlu, S. S. (2011). Vizyon 2023 strateji belgesi ve firsatlart artırma ve teknolojiyi iyileştirme hareketi (FATIH) projesi: Karşılaştırmalı bir inceleme. XIII.Akademik Bilişim Konferans1, Malatya:İnönü Üniversitesi, 115-122.

Aktas, I., Gökoğlu, S., Turgut, Y. E., \& Karal, H. (2014). Öğretmenlerin FATİH projesine yönelik görüşleri: Farkındalık, öngörü ve beklentiler. Necatibey Eğitim Fakültesi Elektronik Fen ve Matematik Ë̆itimi Dergisi, 8(1), 257-286.

Akyüz, H. İ., Pektaş, M., Kurnaz, M. A., \& Memiş, E. K. (2014). Akıllı tahta kullanımlı mikro öğretim uygulamalarının fen bilgisi öğretmen adaylarının TPAB'larına ve akıllı tahta kullanıma yönelik algılarına etkisi. Cumhuriyet International Journal of Education, 3(1), $1-14$.

Angeli, C., \& Valanides, N. (2009). Epistemological and methodological issues for the conceptualization, development, and assessment of ICT-TPCK: Advances in technological pedagogical content knowledge (TPCK). Computers \& Education, 52(1), 154-168.

Ayata, F , Uçkan, T , Çavuş, H , Seyyarer, E . (2021). Öğretmenlerin etkileşimli tahtaya yönelik tutumlarının değerlendirilmesi: Peace with ICT Avrupa birliği proje örneği . Yüzüncü Yll Üniversitesi Eğitim Fakültesi Dergisi, 18 (1), 494-521. Doi: 10.33711/yyuefd.919391

Ayvacı, H., Bakırcı, H., \& Yıldız, M. (2014). Fen bilimleri öğretmenlerinin hizmet içi eğitim uygulamalarına ilişkin görüşleri ve beklentileri. Amasya Üniversitesi Eğitim Fakültesi Dergisi, 3(2), 357-383.

Bağdiken, P., \& Akgündüz, D. (2018). Fen bilimleri öğretmenlerinin teknolojik pedagojik alan bilgisi özgüven düzeylerinin incelenmesi. Gazi Üniversitesi Gazi Eğitim Fakültesi Dergisi, 38(2), 535-566. Doi:10.17152/gefad.357224

Bal, M. S., \& Karademir, N. (2013). Sosyal bilgiler öğretmenlerinin teknolojik pedagojik alan bilgisi (TPAB) konusunda öz-değerlendirme seviyelerinin belirlenmesi. Pamukkale Üniversitesi Eğitim Fakültesi Dergisi, 34(2), 15-32. Doi: 10.9779/PUJE468

Baran, E., \& Canbazoğlu Bilici, S. (2015). Teknolojik pedagojik alan bilgisi (TPAB) üzerine alanyazın incelemesi: Türkiye örneği. Hacettepe Üniversitesi Eğitim Fakültesi Dergisi, 30(1), 15-32.

Bayrak, N., \& Hırça, N. (2016). FATİH Projesi hizmetiçi eğitimine katılan öğretmenlerin tekno-pedagojik özyeterliklerinin incelenmesi. Gazi Üniversitesi Gazi Eğitim Fakültesi 
YYÜ Eğitim Fakültesi Dergisi (YYU Journal of Education Faculty), 2021;18(1)1009-1041,http://efdergi.yyu.edu.tr,

Dergisi, 36(1), 95-111.

Carlson, S., \& Gadio, C. T. (2002). Teacher professional development in the use of technology. Retrieved 07/06/2021, from http://www.ictinedtoolkit.org/usere/library/tech_for_ed_ chapters/08.pdf

Creswell, J. W. (2017). Karma yöntem araştırmalarına giriş (M. Sözbilir, Çev.). Ankara: Pegem Yayıncilik.

Çalışkan, M., \& Çoklar, A. (2019). Öğretmen adaylarının özgüvenleri ile teknoloji kullanımları arasındaki ilişkinin incelenmesi. Ahmet Keleşoğlu Eğitim Fakültesi Dergisi, 1 (2) , 8698. Doi: 10.38151/akef.578807

Demirer, V., \& Dikmen, C. H. (2018). Öğretmenlerin FATİH projesine yönelik görüşlerinin teknolojik pedagojik alan bilgisi bağlamında incelenmesi. Ilkogretim Online, 17(1), 2646. Doi: 10.17051/ilkonline.2018.413735

Enochsson, A., \& Rizza, C. (2009). ICT in initial teacher training: Research review. OECD Education Working Papers, 38, OECD Publishing. Retrieved 07/06/2021, from http://www.oecd.org/edu/ ceri/ceri-ictandinitialteachertrainingresearchreviews.htm.

Erzurum İl Milli Eğitim Müdürlüğü, (2019). Erzurum il milli eğitim müdürlüğü stratejik plan. 10.02.2021 tarihinde http://erzurum.meb.gov.tr/www/erzurum-il-milli-egitim-mudurlu gu-2015-2019-donemi-stratejik-plani/icerik/648 adresinden alınmıştır.

Günbayı, İ., \& Taşdöğen, B. (2012). İlköğretim okullarında çalışan öğretmenlerin hizmet içi eğitim programları üzerine görüşleri: Bir durum çalışması. Insan ve Toplum Bilimleri Araştırmaları Dergisi, 1(3), 87-117.

Graham, C. R., Burgoyne, N., Cantrell, P., Smith, L., Clair St., L., \& Harris, R. (2009). TPACK development in science teaching: Measuring the TPACK confidence of inservice science teachers. TechTrends, 53(5), 70-79. Doi:10.1007/s11528-009-0328-0

Kaleli Yılmaz, G. (2015). Türkiye'deki teknolojik pedagojik alan bilgisi çalışmalarının analizi: Bir meta-sentez çalışması. Eğitim ve Bilim, 40 (178), 103-122. $\quad$ Doi:10.15390/EB. 2015. 4087

Karataş, A., \& Akgün, Ö. E. (2018). Lise öğretmenlerinin FATİH projesi'ni uygulamaya yönelik teknolojik pedagojik alan bilgisi yeterliliklerinin incelenmesi: Adıyaman ili örneği. Medeniyet Ĕgitim Araştırmaları Dergisi, 1(4), 10-30.

Kay, R. H. (2006). Evaluating strategies used to incorporate technology into preservice education: A review of the literature. Journal of Research on Technology in Education, 38(4), 383-408. 
YYÜ Eğitim Fakültesi Dergisi (YYU Journal of Education Faculty), 2021;18(1)1009-1041,http://efdergi.yyu.edu.tr,

Kayaduman, H., Sırakaya, M., \& Seferoğlu, S. S. (2011). Eğitimde FATİH projesinin öğretmenlerin yeterlik durumları açısından incelenmesi. Akademik Bilişim, 11, 123-129. Keleşoğlu, S., \& Yiğit, E. Ö. (2017). Yenilikçi tarih öğretimi hizmet içi eğitim programının öğretmen görüşlerine dayalı olarak değerlendirilmesi. Journal of Faculty of Educational Sciences, 50(1), 161-187. Doi: 10.1501/Egifak_0000001391

Kilmen, S. (2015). Eğitim araştırmacıları için SPSS uygulamalı istatistik. Ankara: Edge Akademi Yayınları.

Kocaoğlu, B. Ü., \& Akgün, Ö. E. (2015). Lise öğretmenlerinin FATİH projesi teknolojilerini kullanmaya yönelik öz-yeterlilik inançları. Uluslararası Eğitim Bilimleri Dergisi, 4, 259276. Doi: 10.16991/INESJOURNAL.81

Lehiste, P. (2015). The impact of a professional development program on in-service teachers' TPACK: A study from Estonia. Problems of Education in the 21st Century, 66, 18-28.

Limon, İ. (2014). Yüz yüze ve uzakan hizmet içi eğitim faaliyetlerine yönelik öğremten algıları (Sakarya ili örneği) (yayımlanmamış yüksek lisans tezi). Sakarya Üniversitesi, Sakarya.

MEB. (2016). Fatih projesi öğretmen ĕgitimleri. 07.06.2021 tarihinde http://turgutlu.meb. gov.tr/meb_iys_dosyalar/2016_10/14092100_fatih_projesi_ogretmen_egitimleri.pdf adresinden alınmıştır.

MEB. (2020). Fatih projesi. 07.06.2021 tarihinde http://fatihprojesi.meb.gov.tr/about.html adresinden alınmıştır.

Meriç, G. (2014). Fen ve teknoloji öğretmen adaylarının teknolojik pedagojik alan bilgisi konusunda öz güven seviyelerinin belirlenmesi. Eğitimde Kuram ve Uygulama, 10(2), 352-367.

Miles, M. B., \& Huberman, A. M. (1994). Qualitative data analysis: An expanded sourcebook. Sage.

Mishra, P., \& Koehler, M. J. (2006). Technological pedagocical content knowledge: A framework for teacher knowledge. Teacher College Record, 108(6), 1017-1054. Doi:10.1111/j.1467-9620.2006.00684.x

Niess, M. L. (2008). Guiding preservice teachers in developing TPCK. Routledge.

Öçal, M. F., \& Şimşek, M. (2017). Matematik öğretmen adaylarının FATİH projesi ve matematik eğitiminde teknoloji kullanımına yönelik görüşleri. Turkish Online Journal of Qualitative Inquiry, 8(1), 91-121. Doi: 10.17569/tojqi.288857

Özkara, E. C., Konokman, G. Y., \& Yelken, T. Y. (2018). Eğitimde teknoloji kullanımı hizmetiçi eğitimine katılan öğretmenlerin TPAB özgüvenlerinin incelenmesi. Amasya 
Üniversitesi Ĕgitim Fakültesi Dergisi, 7(2), 371-412.

Padmavathi, M. (2017). Preparing teachers for technology based teaching-learning using TPACK. Journal on School Educational Technology, 12(3), 1-9.

Polly, D., Mims, C., Shepherd, C. E., \& Inan, F. (2010). Evidence of impact: Transforming teacher education with preparing tomorrow's teachers to teach with technology (PT3) grants. Teaching and Teacher Education, 26(4), 863-870.

Sarıtepeci, M., Durak, H., \& Seferoğlu, S. S. (2016). Öğretmenlerin öğretim teknolojileri alanında hizmet-içi eğitim gereksinimlerinin FATİH projesi kapsamında incelenmesi. Turkish Journal of Computer and Mathematics Education, 7(3), 601-620. Doi:10.16949/turkbilmat.277873

Shulman, L. (1986). Those who understand: Knowledge growth in teaching. Educational Researcher, 15(2), 4-14. Doi: 10.3102/0013189X015002004

Somyürek, S. (2014). Öğretim sürecinde Z kuşağının dikkatini çekme: Artırılmış gerçeklik. Educational Technology Theory and Practice, 4(1), 63-80. doi:10.17943/etku.88319

Taşlıbeyaz, E., \& Karaman, S. (2014). Uzaktan hizmetiçi eğitim alan öğretmenlerin deneyimlerinin İncelenmesi. 7. Uluslararası Bilgisayar ve Öğretim Teknolojileri Sempozyumu, Atatürk Üniversitesi, Erzurum. Doi: 10.12984/eed.19099

Tatlı, Z., İpek Akbulut, H., \& Altınışık, D. (2016). The impact of web 2.0 tools on pre-service teachers' self confidence levels about TPCK. Turkish Journal of Computer and Mathematics Education, 7(3), 659-678. Doi: 10.16949/turkbilmat.277878

Tatli, Z., \& Akbulut, H. İ. (2017). Öğretmen adaylarının alanda teknoloji kullanımına yönelik yeterlilikleri. Ege Ĕ̆itim Dergisi, 18(1), 31-55. Doi: 10.12984/egeefd.328375

Timur, B., \& Taşar, M. F. (2011). Teknolojik pedagojik alan bilgisi öz güven ölçeğinin (TPABÖGÖ) Türkçe 'ye uyarlanması. Gaziantep Üniversitesi Sosyal Bilimler Dergisi, 10(2), 839-856.

Tokmak, H. S., İncikabi, L., \& Özgelen, S. (2013). An investigation of change in mathematics, science, and literacy education pre-service teachers' TPACK. The Asia-Pacific Education Researcher, 22(4), 407-415. Doi: 10.1007/s40299-012-0040-2

Tondeur, J., Roblin, N. P., Van-Braak, J., Fisser, P., \& Voogt, J. (2013). Technological pedagogical content knowledge in teacher education: In search of a new curriculum. Educational Studies, 39(2), 239-243.

Tschannen-Moran, M., Hoy, A. W., \& Hoy, W. K. (1998). Teacher efficacy: Its meaning and measure. Review of Educational Research, 68(2), 202-248. 
YYÜ Eğitim Fakültesi Dergisi (YYU Journal of Education Faculty), 2021;18(1)1009-1041,http://efdergi.yyu.edu.tr,

Doi:10.3102/00346543068002202

Uçar, M. B., Demir, C., \& Hiğde, E. (2014). Exploring the self-confidence of preservice science and physics teachers towards technological pedagogical content knowledge. ProcediaSocial and Behavioral Sciences, 116, 3381-3384. Doi: 10.1016/j.sbspro.2014.01.768

Vural, A. R., \& Ceylan, V. K. (2014, Kasım). Fatih projesi eğitimde teknoloji kullanım kursunun öğretmen görüşlerine göre değerlendirilmesi. XIX. Türkiye'de İnternet Konferansında sunulan sözlü bildiri. Yaşar Üniversitesi, İzmir.

Wang, W., Schmidt-Crawford, D., \& Jin, Y. (2018). Preservice teachers' TPACK development: A review of literature. Journal of Digital Learning in Teacher Education, 34(4), 234-258. Doi: 10.1080/21532974.2018.1498039

Yılmaz, M. ve Üredi, L. (2020). İlkokul öğretmenlerinin eğitimde teknoloji kullanımına ilişkin bilgisayar yeterliliklerinin değerlendirilmesi. OPUS-Uluslararası Toplum Araştırmaları Dergisi, 16(32), 4723-4742. Doi: 10.26466/opus.779338 


\section{Summary}

\section{Statement of Problem}

FATIH Project (Movement to Increase Opportunities and Improve Technology) was implemented by the Ministry of National Education in Turkey in 2010. Project has five component which most important one is in service education of teachers (MEB, 2020). The Ministry of National Education has requested that the entire teacher participate in the service training under the name of "technology use in education course" or "interactive classroom management course". Thanks to FATIH project, most teachers have participated in service training on the use of technology in education.

Today, due to the Covid 19 pandemic, the importance of actively using technology in education has been raised. Bayrak and Hırça (2016), Demirer and Dikmen (2018), Kayaduman et al. (2011), Sarıtepeci et al., (2016), Tatlı and Akbulut (2017) revealed that the teacher in Turkey was inadequate to use technology in education. Despite the above-mentioned largescale in-service activity on the use of technology in education, the inadequacy of teachers' situations regarding educational technologies is an issue that needs to be investigated in every aspect.

In this study, technological pedagogical content knowledge (TPACK) self-confidence was selected to investigate the impact of in-service courses on using technology for education. Direction self-confidence about technological pedagogical content knowledge is an important indicator for using technology in education (Kayaduman et al., 2011; Tatli and Akbulut, 2017).

Self-confidence by short definition; is a belief in the ability to organize and conduct the necessary activities to fulfill the teaching task. The ability of teachers is a criterion that will positively affect the teaching process. One of the sought-after teacher qualities is that the teacher is qualified for technological pedagogical content knowledge. It is thought that technology-supported courses will be better understood and remembered by students (Bağdiken and Akgündüz, 2018; Mishra and Koehler, 2006). Therefore, teachers should use technology effectively and efficiently, literate technology (Bağdiken and Akgündüz, 2018; Niess, 2008).

The majority of studies on TPACK in scope of Turkey; focuses on competence, development, scale development and program evaluation about TPACK (Baran and Canbazoglu Bilici, 2015; Kaleli Yilmaz, 2015). Again, most of the studies were done with preservice teachers, the number of studies with teachers is quite low (Kaleli-Yilmaz, 2015). 
The first aim of the study is to examine in-effect courses that examine the teacher's selfconfidence in TPACK using technology in education. The trainings attended by teachers on the use of technology in education undoubtedly have a significant impact on the self-confidence of technological pedagogical content knowledge (Bağdiken and Akgündüz, 2018; Kocaoglu and Akgün, 2015). Bal and Karademir (2013), Özkara et al. (2018) found that teachers who participated in educational technologies trainings had higher TPACK self-esteem than those who did not receive education. Kocaoglu and Akgün (2015) found that teachers attending FATIH project training technology use courses had high self-confidence in using FATIH project equipment. In all four studies, it has been proposed to increase in-service education and ensure that more teachers attend these courses. In-service courses on the use of technology in face-to-face education have an impact on self-confidence development (Izci and Eroglu, 2016), but in some studies it has been emphasized that in-service courses cannot meet the needs of teachers (Sarıtepeci et al., 2016) and are inadequate to gain techno-pedagogical skills (Vural and Ceylan, 2014). However, there is no information on whether in-service training is distanced or face-to-face, and whether teachers' voluntary or involuntary participation in lessons has an impact on TPACK self-esteem.

In this context, the following questions were sought in the study:

What are the TPACK self-confidence levels of the teachers participating in the study?

TPACK self-confidence of the teachers participating in the study; Is there a difference according to variables such as taking information technologies (IT) course during undergraduate education, attending in-service courses on the use of technologies in education, whether the courses they attend are remote or face-to-face, voluntary or involuntary participation?

\section{Method}

In the study, one of the designs in mixed research, see in sequence descriptive design was used (Creswell, 2017).

Quantitative data is first collected and analyzed in the sequence descriptive design, then qualitative work is done to explain quantitative results (Creswell, 2017). In this study, data were collected primarily from teachers with the help of a scale, analyzed, and semi-structured interviews with teachers who participated in or trained in in-service training to explain the results of the analysis.

Quantitative data collected 241 science, physics, biology and chemistry teachers. "Technological pedagogical content information self-confidence scale" and "personal 
information form" were used as data collection tools. Qualitative data were collected with a form consisting of semi-structured interview questions conducted with 18 teachers.

Quantitative data were analyzed with SPSS 22 program. During university education, the percentage and frequent values of the information related to the status of attending the IT course and participation in in-service training courses related to the use of technology in education were calculated. The averages of the data were analyzed to determine TPACK selfconfidence.

Audio recordings of the interview were analyzed and transferred to the MAXQDA 2020 program, taking into account the notes kept during the interview for the analysis of qualitative data. In the Maxqda 2020 program, interview data were analyzed repeatedly by two researchers. After the analysis, the researchers came together to identify the points where they had consensus or disagreement on coding. The researchers used Miles and Huberman's (1994) reliability formula to calculate the consistency rate of their coding, with an average similarity of 92.5\%. Examples of the statements of the teachers who participated in the study were presented during the presentation of qualitative data.

\section{Discussion and Conclusion}

The information technology training that teachers receive during university education has increased their self-confidence in terms of technological knowledge. This result was consistent with the findings of Öçal and Simsek, (2017), Tatlı and Akbulut (2017) that preservice teachers failed to adequately integrate the technological knowledge they learned during university education into the teaching process. In recent years, the special knowledge of technology education given during university education can improve the technological knowledge dimension as well as other sub-dimensions of TPACK self-confidence, but when the teachers who participate in the study graduate, the lack of knowledge technological education at the university can be explained as a result of the study. In addition, in today's day when technology is constantly progressing, changing and transforming, it can be considered normal that the trainings that teachers receive during university education are inadequate, but the main problem here is that the teachers who receive this training cannot apply for change. In this respect, the education provided at the university should be of a quality that encourages teachers to improve themselves.

Participation in a course on the use of technology in education within the scope of FATIH project positively affected teachers' self-confidence in TPACK, technological content knowledge (TCK), technological pedagogical knowledge (TPK) sub-dimensions. In the 
literature, Bağdiken and Akgündüz (2018) found that they had a positive effect on all dimensions and that the teachers who participated in the in-service training of Bal and Karademir (2013), Kocaoğlu and Akgün (2015), Özkara et al. (2018) felt safer in terms of TPACK. However, in our study, in-service education has not had a significant impact on selfconfidence in technological knowledge (TK) dimensions to the use of technology in education. The reasons for this situation may be that the content of the course is inadequate in terms of technological knowledge, and that topics such as video editing presented as technological information are forgotten due to the use of ready-made materials by teachers. Tatl and Akbulut (2017) stated that teachers' use of ready-made course materials and gaining habits in this regard will blunt their own content production competencies. There may not be enough time left to teach planned content, especially since face-to-face lessons are in the evening hours.

Teachers participating in in-service training have no difference in TPACK selfconfidence, just distance or just face-to-face. While there is less content and interaction in distance education, it's noteworthy that teachers don't get left without face-to-face training on TPACK self-esteem. Especially in face-to-face training, the inability to use time effectively may lead to a decrease in the effectiveness of face-to-face courses, as the class hours are in the evenings. The findings of the inadequacy of the course duration and the duration of the course are similar to the work of Günbayı and Taşdöğen (2012). Another reason that reduces the success of the effects of face-to-face courses may be the inadequacy of educators, first of all, course educators should be selected from among the educators who apply the content they teach during the teaching process. In this regard, Keleşoğlu and Yigit (2017) recommends that educators working in in-service trainings be selected among the competent teachers in their field with at least a PhD degree. Ayvac1 et al. (2014) states that having classroom experience of educators in general in-service trainings is even more important in in-service trainings related to the use of technology in education. The fact that educators have particularly high communication skills (Günbayı and Taşdöğen, 2012) and can give examples of how to use this information in their fields when teaching content can contribute significantly to achieving the purpose of in-service training. In order to share the experiences and ideas of participating teachers in the subjects receiving education, it can be used as an advantage for the teachers participating in face-to-face training to be from the same discipline.

In-service trainings carried out through distance education; insufficient content, difficulty getting support, technical problems are the most common challenges. Similar results are present in Limon's (2014) study. Again, there are fraudulent participation problems due to 
the difficulty of measuring and evaluating at the end of remote in-service training and the lack of control mechanisms during or at the end of the training. However, if you don't distance education can be preferred by the teacher due to the convenience of time and space (Limon, 2014; Taslibeyaz and Karaman, 2014), but can be preferred more if face-to-face training conditions are appropriate. Having difficulty getting interaction and support, which are seen as the weaknesses of distance education, is the superior aspects of face-to-face in-service education.

Interactive, practical trainings are more recommended in FATIH project trainings (Demirer and Dikmen, 2018). However, face-to-face in-service training is one that requires teachers to be at certain times and in a specific place. This requires the use of both time and financial resources to create in-service fields. Instead of face-to-face training, a model where teachers can receive theoretical parts of the content of in-service training with distance education and can only do face-to-face training in practical parts can prevent waste of time and resources. In addition, gradual planning and meeting the needs of the courses in accordance with the level of trainee teachers, bringing together teachers from the same discipline when accepting trainees can be beneficial for in-service training to achieve its goals.

The participation of teachers in in-service training with them will positively affect TPACK self-confidence in all its sub-dimensions. Teachers who voluntarily participate in inservice training have higher TPACK self-confidence than teachers who involuntarily participate. In this respect, it is considered important to attend the course not by a compelling method for the development of TPACK self-confidence, but by persuading teachers and making them feel that the course is necessary for them. As a matter of fact, Günbayı and Taşdöğen (2012) stressed that voluntary participation in the course was the most important factor affecting the success of the purpose in in-service trainings. For this purpose, teachers who participate in in-service training can be given points that will contribute to the career ladder. It can also be useful if time or course venues are attractive for teachers to attend the course. Even better, after the appropriate environment is provided, the teacher will be persuaded by noticing the benefits of in-service training. 